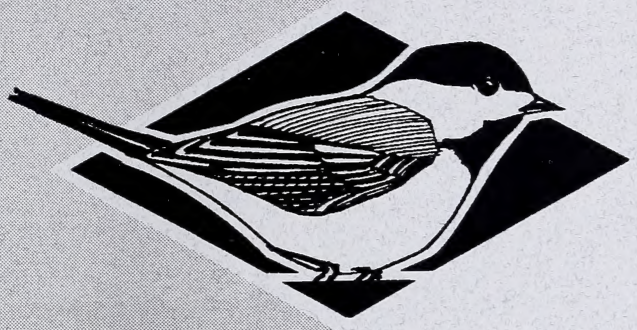

\title{
Status of the Prairie Rattlesnake (Crotalus viridis viridis) in Alberta
}

Sheri M. Watson

Anthony P. Russell

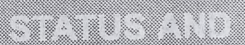

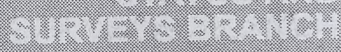

Alberta Wildlife Status Report No. 6

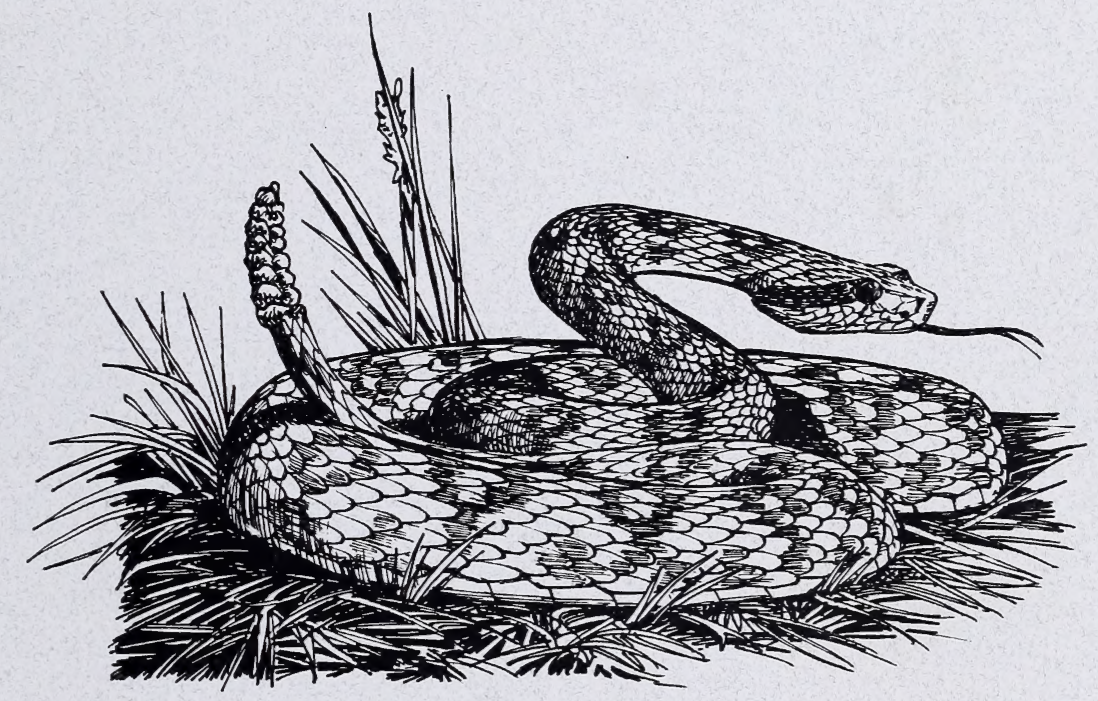

ind 


\section{of Canada $\begin{aligned} & \text { National Library } \\ & \text { of Cibliotheque nationale } \\ & \text { du Canada }\end{aligned}$}




\title{
Status of the Prairie Rattlesnake (Crotalus viridis viridis) in Alberta
}

\author{
Sheri M. Watson \\ Anthony P. Russell
}

Alberta Wildlife Status Report No. 6

Published By:

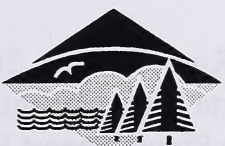


Publication No. T/369

ISBN: 0-7732-5131-6

ISSN: $1206-4912$

Series Editor: David R. C. Prescott

Illustrations: Brian Huffman

For copies of this report, contact:

Information Centre - Publications

Alberta Environmental Protection

Natural Resources Service

Main Floor, Bramalea Building

9920 - 108 Street

Edmonton, Alberta, Canada T5K 2M4

Telephone: (403) 422-2079

OR

Communications Division

Alberta Environmental Protection

\#100, 3115 - 12 Street NE

Calgary, Alberta, Canada T2E 7J2

Telephone: (403) 297-3362

This publication may be cited as:

Watson, S. M., and A. P. Russell. 1997. Status of the Prairie Rattlesnake (Crotalus viridis viridis) in Alberta. Alberta Environmental Protection, Wildlife Management Division, Wildlife Status Report No. 6, Edmonton, AB. 26 pp. 


\section{PREFACE}

Every five years, the Wildlife Management Division of Alberta Natural Resources Service reviews the status of wildlife species in Alberta. These overviews, which have been conducted in 1991 and 1996, assign individual species to "color" lists which reflect the perceived level of risk to populations which occur in the province. Such designations are determined from extensive consultations with professional and amateur biologists, and from a variety of readily-available sources of population data. A primary objective of these reviews is to identify species which may be considered for more detailed status determinations.

The Alberta Wildlife Status Report Series is an extension of the 1996 Status of Alberta Wildlife review process, and provides comprehensive current summaries of the biological status of selected wildlife species in Alberta. Priority is given to species that are potentially at risk in the province (Red or Blue listed), that are of uncertain status (Status Undetermined), or which are considered to be at risk at a national level by the Committee on the Status of Endangered Wildlife in Canada (COSEWIC).

Reports in this series are published and distributed by the Wildlife Management Division of Alberta Environmental Protection, and are intended to provide detailed and up-to-date information which will be useful to resource professionals for managing populations of species and their habitats in the province. The reports are also designed to provide current information which will assist the proposed Alberta Endangered Species Conservation Committee to identify species that may be formally designated as endangered or threatened under the Alberta Wildlife Act. To achieve these goals, the reports have been authored and/or reviewed by individuals with unique local expertise in the biology and management of each species. 


\section{EXECUTIVE SUMMARY}

The Western Rattlesnake (Crotalus viridis) is found throughout much of western North America. Throughout its range, the species has been subjected to intense persecution, and much of its habitat has been altered by human activities. As a result, populations of rattlesnakes appear to be decreasing in numbers in many areas. The species is currently included on the "Blue List" of wildlife that may be at risk in both British Columbia and Alberta, and has been described as being "threatened" in Saskatchewan. This report reviews current information on the Prairie Rattlesnake ( $\underline{\mathrm{C}} . \underline{\mathrm{v}}$. viridis), the subspecies of the Western Rattlesnake which occurs in Alberta, as a first step in updating its status in this province.

In Alberta, the Prairie Rattlesnake is primarily distributed along major river drainages in the southeastern portion of the province. Historically, the species was found as far north as Trochu, and as far west as Calgary. However, the range has apparently contracted towards the east and south, but has remained relatively unchanged since 1977. Large populations persist in some areas of the province, but there is evidence that populations at many den sites have experienced recent or long-term decline in numbers.

The Prairie Rattlesnake is at the northern edge of its range in Alberta, and the availability of suitable overwintering hibernacula is likely a major factor limiting abundance and distribution. The species has a low reproductive potential, and would be slow to recover from population declines which may now be occurring. Current threats to the provincial population include the loss or alteration of native grassland habitat, mortality associated with roads and pipeline construction, and intentional killing of snakes and vandalism of den sites. A number of initiatives are now underway in the province that will improve our knowledge of Prairie Rattlesnakes, and that will hopefully lead to better management and public perception of the species in the future. 


\section{ACKNOWLEDGEMENTS}

A number of individuals made significant contributions to the successful completion of this report. Although all assistance was deeply appreciated, a few individuals deserve special consideration. We are greatly indebted to Larry Powell for his counsel, for generously providing information, and for critically reviewing earlier drafts of this manuscript. We are also grateful to Dave Prescott and Steve Brechtel (Alberta Natural Resources Service), Andy Didiuk (Canadian Wildlife Service), and Dave Scobie (Operation Grassland Community) for reviewing the first draft of the manuscript; their comments and insights were very much appreciated. We also thank Delinda Ryerson (Alberta Natural Resources Service) for editorial assistance, and Jane Horb for drafting the maps. Also, special thanks to Graham MacGregor for his support and constant encouragement. Production of this report was supported by the Wildlife Management Enhancement Fund of Alberta Natural Resources Service and the Alberta Conservation Association.

Information for this report was gathered from a number of sources, and we would like to acknowledge those individuals and agencies who contributed information, both directly or indirectly. Contributors denoted with an asterisk $\left({ }^{*}\right)$ provided records used for determining the current range (see Figure 1). The following individuals are listed alphabetically, but deserve equal consideration; Robert Barclay (University of Calgary), Steve Brechtel (Alberta Natural Resources Service), Doug Collister (URSUS Ecosystem Management Ltd.), Dave Crooks (Dinosaur Provincial Park), Adrien Corbiere (Lethbridge Naturalist Society), Ann Dalton (Montana Natural Heritage Program), Andrew Didiuk* (Canadian Wildlife Service), Dale Eslinger* (Alberta Natural Resources Service, Medicine Hat), Express Pipeline Ltd., Pat Fargey (Parks Canada), Laura Friis (B.C. Environment, Wildlife Branch), David Genter (Montana Natural Heritage Program), Joyce Gould (Alberta Natural Resources Service), Wayne Harris (Saskatchewan Fish and Wildlife), Mike Hauser (Express Pipeline Ltd.), Ed Hofman* (Alberta Natural Resources Service, Hanna), Robert Hugill (Dinosaur Provincial Park), Andy Hurley (University of Lethbridge), Janice James* (University of Calgary), Ann Lane* (Royal Tyrrell Museum), Rick Lauzon* (DELTA/AXYS Environmental Management Group Ltd.), Lethbridge Naturalists' Society*, Rob Morrison (Alberta Natural Resources Service, Foremost), National Museum of Canada*, L. Powell* (University of Calgary), Wayne Roberts* (University of Alberta Museum), Edward Ruff, Reg Russell (Alberta Natural Resources Service, Brooks), Delinda Ryerson* (Alberta Snake Hibernaculum Inventory), Elizabeth Saunders* (Helen Schuler Coulee Centre), Dave Scobie (Operation Grassland Community), Paulette Sheilds* (Alberta Natural Resources Service, Lethbridge), Simon Shonhofer (Majestic Ranch), Wayne Smith*, Howard Troughton* (Palliser Pipeline Project), Cliff Wallis (Cottonwood Consultants Ltd.), Robert Ward* (Writing-on-Stone Provincial Park), Earl Wiltse (Saskatchewan Environment and Resource Management), Robert Wolfe (Alberta Environmental Protection), and the University of Calgary Map Department. 


\section{TABLE OF CONTENTS}

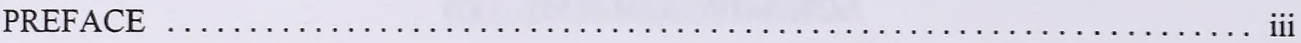

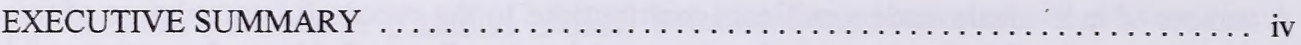

ACKNOWLEDGEMENTS $\ldots \ldots \ldots \ldots \ldots \ldots \ldots \ldots \ldots \ldots \ldots \ldots \ldots \ldots \ldots \ldots \ldots$

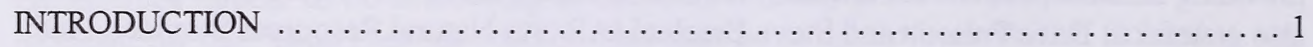

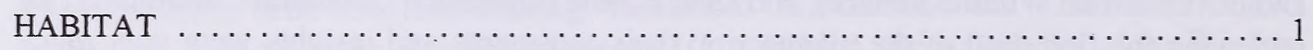

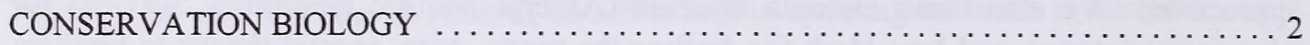

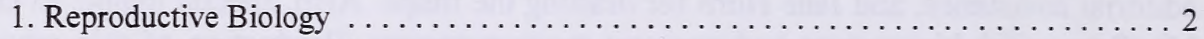

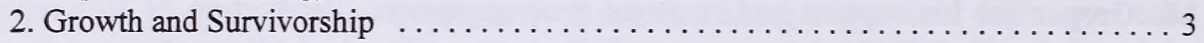

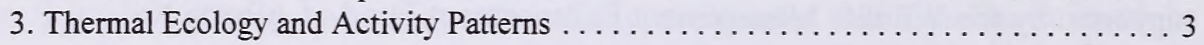

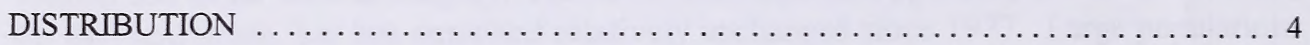

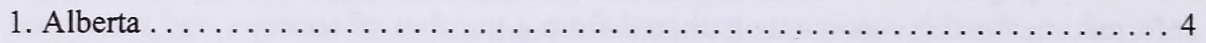

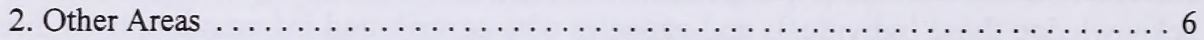

POPULATION SIZE AND TRENDS $\ldots \ldots \ldots \ldots \ldots \ldots \ldots \ldots \ldots \ldots \ldots \ldots \ldots \ldots \ldots$

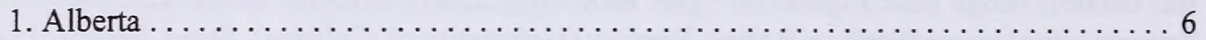

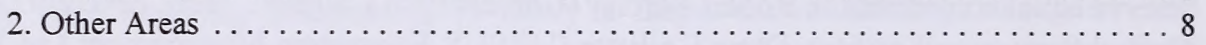

LIMITING FACTORS $\ldots \ldots \ldots \ldots \ldots \ldots \ldots \ldots \ldots \ldots \ldots \ldots \ldots \ldots \ldots \ldots \ldots \ldots$

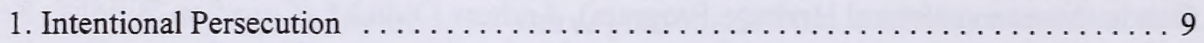

2. Roads and Pipeline Construction . . . . . . $\ldots \ldots \ldots \ldots \ldots \ldots \ldots \ldots \ldots$

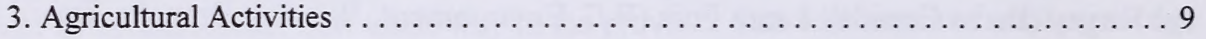

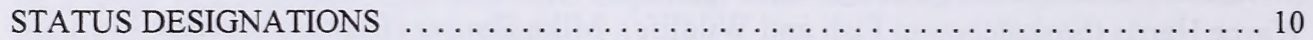

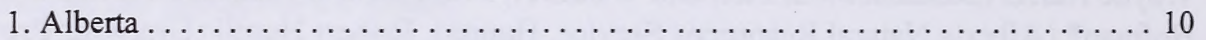

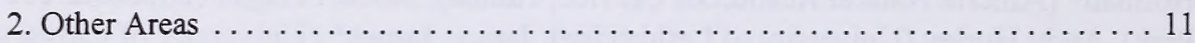

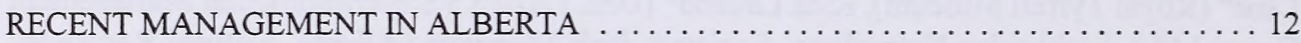

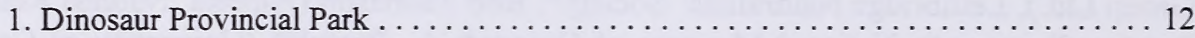

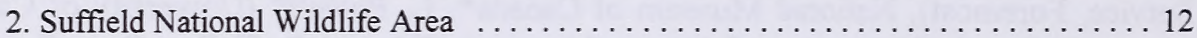

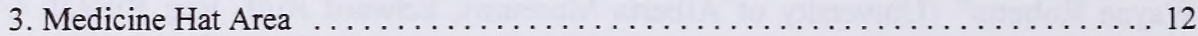

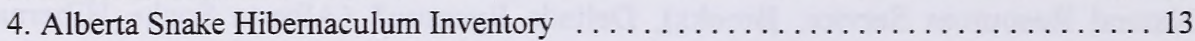

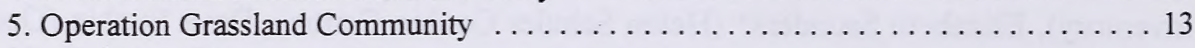

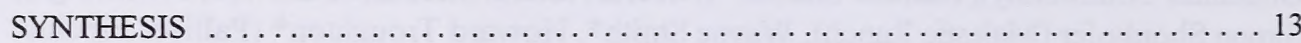

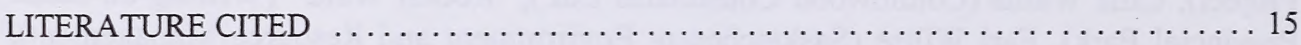

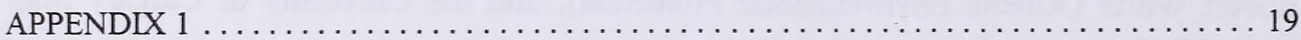

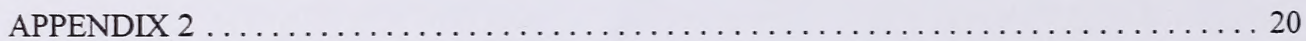

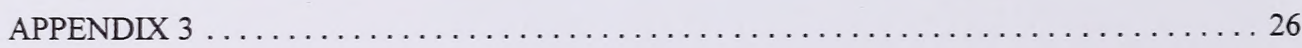




\section{INTRODUCTION}

Of the eight subspecies of the Western Rattlesnake (Crotalus viridis) in North America, the Prairie Rattlesnake, $\underline{\mathrm{C}}$. $\underline{\mathrm{v}}$. viridis, is the only one found in Alberta (Behler and King 1979, Russell and Bauer 1993). Although some general comments on distribution and biology of the Western Rattlesnake are provided, this report focuses more specifically on literature about the subspecies which occurs in Alberta.

The Prairie Rattlesnake varies in distribution and abundance throughout its range. In Alberta, for example, the Prairie Rattlesnake is a "Blue-listed"" species, indicating that it may be "at risk" and susceptible to habitat disturbance, population decline, or reductions in provincial distribution (Alberta Wildlife Management Division 1996). In Saskatchewan, its distribution is limited and it is thought to be "threatened" (Secoy 1987), whereas in Montana, this subspecies is considered to be widely distributed and abundant (Reichel and Flath 1995, D. Genter, pers. comm.).

This report summarizes historical as well as recent information on the Prairie Rattlesnake as a step in updating the status of this species in Alberta.

\section{HABITAT}

The habitat of the Prairie Rattlesnake in Canada has been described as mixed-grass prairie (includes both mid- and short grasses; Anonymous 1994, Cottonwood Consultants 1987, Coupland 1961), or as short-grass prairie (Cook 1984, McCorquedale 1965, Russell and Bauer 1993). The semi-arid climate of the mixed-grass prairie is characterized by low precipitation, high summer temperatures, and a short growing season (Coupland 1961), whereas the short-grass prairie occurs under even drier conditions or intense grazing pressure (Anonymous 1994).

In Alberta, the Prairie Rattlesnake is found within the Grassland Natural Region (Alberta Fish and Wildlife 1991), often associated with river and coulee bottoms, badlands, sage flats, and less commonly on open short-grass prairie (Halladay 1965, Lewin 1963). Gannon (1978) surveyed the habitat surrounding Prairie Rattlesnake hibernacula (overwintering dens) in Alberta and Saskatchewan and found that, although local topography and vegetation varied between sites, the habitat consistently encompassed both a river valley and the surrounding prairie.

Hibernacula, which allow $\underline{\text { C. }} \underline{\mathbf{v}}$. viridis to survive through long cold winters, are a critical component of Prairie Rattlesnake habitat in northern climates (Blood 1993, Gannon 1978, MacArtney and Weichel 1989). Slump blocks, meander scarps, subterranean water channels, rock outcrops, and mammal burrows have all been found to provide suitable conditions for hibernacula (Cottonwood Consultants 1987, Gannon 1978, Russell and Bauer 1993). Hibernacula are usually found on south-facing slopes which provide maximum solar insulation, while offering protection from prevailing winds (Gannon 1978, MacArtney et al. 1990). However,

* See Appendix 1 for definitions of selected status designations. 
a small number of dens appear to be located on, or adjacent to, east- or north-facing slopes (Cottonwood Consultants 1987). Overwintering dens of the Prairie Rattlesnake are often shared with other species such as Bull Snakes (Pituophis melanoleucus) and Garter Snakes (Thamnophis spp.; Cottonwood Consultants 1987, Duvall et al. 1985, Gannon and Secoy 1985, Russell and Bauer 1993).

Rattlesnakes return to their dens each fall, and therefore hunting and basking areas must be available within a reasonable distance from the hibernaculum (Blood 1993, Charland et al. 1993). Habitat characteristics of basking and foraging sites have received limited study, but talus slopes adjacent to dens appeared to serve as basking areas for rattlesnake populations in British Columbia (see MacArtney 1985, in Charland et al. 1993), and foraging sites were apparently determined by the concentration of local rodent populations in a Wyoming study (Duvall et al. 1990).

Another potential habitat requirement of the rattlesnake is the presence of a suitable birthing area or rookery where gravid females can aggregate until parturition. Although only a small number of rookeries have been found, these areas have some common features, including the presence of large, flat table rocks overlaying abandoned mammal burrows (Duvall et al. 1985, Gannon and Secoy 1985, Keenlyne 1972). It has been suggested that these habitat characteristics provide quick escape from predators as well as appropriate microhabitat for thermoregulation (Keenlyne 1972). At the proposed Suffield National Wildlife Area in Alberta, no evidence of large aggregations at rookeries was found. However, limited observations suggested one or two gravid females selected small burrows at the rim of escarpments which also provided good basking conditions and escape from predators (A. Didiuk, unpubl. data).

It has been estimated that over two-thirds of the original mixed-grass prairie has been destroyed (Anonymous 1994, Wallis 1987). This loss, in combination with increased grazing and the construction of roadways and pipelines on the prairies suggest that the availability of suitable habitat for Prairie Rattlesnakes may be declining in the province.

\section{CONSERVATION BIOLOGY}

The effectiveness of conservation and management actions is strongly reliant on our understanding of species' biology. For the Prairie Rattlesnake, aspects of its reproductive biology, growth, survivorship, thermal ecology, and activity patterns are of potential importance for conservation and management decisions.

1. Reproductive Biology. - Mating in $\underline{\mathrm{C}} . \underline{\mathrm{v}}$. viridis occurs during mid- to late summer and possibly in early fall (Alderidge 1993, Duvall et al. 1985, Russell and Bauer 1993, but see Holycross 1995). Young are born the following year, between late August to mid-October in Canada (Charland 1989, MacArtney and Weichel 1993, MacArtney et al. 1990), with litter size ranging from four to 12 (Kissner et al. 1996, Russell and Bauer 1993, Trottier and Didiuk 1995). Sexual maturity for male Prairie Rattlesnakes occurs at three to four years of age (MacArtney et al. 
1990), whereas females are thought to attain sexual maturity between five and seven years of age. Females appear to follow a biennial or triennial reproductive cycle at high latitudes (Gannon and Secoy 1984, Russell and Bauer 1993, MacArtney et al. 1990, MacArtney and Weichel 1993), although in Saskatchewan, four females were found to be pregnant in two consecutive years indicating that annual reproduction can occur (Kissner et al. 1996). The reproductive biology of Prairie Rattlesnakes, with characteristics such as late reproductive maturity, relatively small litters, and biennial or triennial reproductive cycles, indicates that the reproductive capacity and recruitment levels for this species are relatively low (Charland et al. 1993, MacArtney and Weichel 1989).

\section{Growth and Survivorship. -} Rattlesnakes at higher latitudes typically experience slower growth rates and greater overwintering weight loss than individuals from more southern populations (Gannon and Secoy 1984, MacArtney et al. 1990). For example, snout-vent lengths of one-, two-, and three-year old Western Rattlesnakes in central California (Fitch 1949), were found to be approximately equal to three-, four-, and five-year old rattlesnakes in British Columbia (MacArtney et al. 1990). Similarly, overwintering weight loss in Western Rattlesnakes in northern Utah was found to be four to nine percent of body weight (Parker and Brown 1974), whereas overwintering weight loss in Saskatchewan populations ranged from 7.1 to $13.9 \%$ of total weight (Gannon and Secoy 1984).

Although comparative data from lower latitudes are not available, studies of rattlesnake populations in British Columbia and Saskatchewan demonstrate that overwintering survival in young of the year can be poor (as low as $0 \%$ in some years; Charland 1989, Charland et al. 1993, Gannon and Secoy 1984, MacArtney and Weichel 1993). Slow growth rate, high overwintering weight loss, and poor juvenile survivorship are indicative of the harsher conditions faced by rattlesnake populations inhabiting higher latitudes.

\section{Thermal Ecology and Activity}

Patterns. - Snake populations in cold climates often develop specific behavioral and physiological strategies for dealing with a shortened active season (see Gannon and Secoy 1985). In Alberta, Prairie Rattlesnake populations reach the northern limit of their distribution (MacArtney and Weichel 1989, McCorquedale 1965), and restrictions imposed by the colder climate should be reflected in their thermal ecology.

At high latitudes, such as in Saskatchewan, British Columbia, or Idaho, the active period for rattlesnakes lasts only five to seven months (from late April to early October; Gannon and Secoy 1985, MacArtney et al. 1990), in comparison to 8.5 months for populations in Wyoming (Duvall et al. 1990). In addition, southern populations of $\underline{C}$. viridis may be active above ground during occasional warm spells in winter, whereas hibernation is continuous for northern rattlesnakes (MacArtney et al. 1990). Rattlesnakes at more northern latitudes also appear to experience lower body temperatures during hibernation (Jacob and Painter 1980, MacArtney et al. 1989). 
A greater understanding of the thermal ecology of Prairie Rattlesnakes in Alberta, during both hibernation and the active season, may provide insight into factors restricting distribution in this species (e.g., additional habitat requirements necessary for effective thermoregulation).

Knowledge of activity patterns in rattlesnakes may also be critical for understanding habitat requirements. During the active season, rattlesnakes may migrate long distances from their overwintering dens (Parker and Brown 1974). At the proposed Suffield National Wildlife Area in Alberta, radio-tagged males and post-gravid females travelled up to $24 \mathrm{~km}$ from their hibernacula (A. Didiuk, unpubl. data). In a study in British Columbia, however, the greatest migration distance was only $1575 \mathrm{~m}$ from the hibernaculum, and distances more commonly ranged from 1100 to $1300 \mathrm{~m}$ from the den (Charland et al. 1993).

In the spring, migration appears to be associated with a search for suitable foraging areas (Duvall et al. 1985, 1990). Gravid females of $\underline{\text { C. viridis do not feed }}$ during gestation (Duvall et al. 1985, MacArtney et al. 1990, Russell and Bauer 1993), and over the summer months may aggregate at birthing rookeries which are usually close to the denning area (Gannon and Secoy 1985). The purpose of aggregation in gravid females is unknown; however, it has been suggested that effective thermoregulation is necessary for proper embryonic development, and that aggregation may result from limited availability of incubation sites (Charland and Gregory 1990, Gannon and Secoy 1985). Following parturition, females and neonates remain together at the rookery for several days before dispersing. It has been suggested that these postpartum aggregations allow neonates to recognize conspecific odours that are later used for initial den location (Duvall et al. 1985, Graves et al. 1986).

\section{DISTRIBUTION}

1. Alberta. - The current distribution of the Prairie Rattlesnake in Alberta (Figure 1) is based on 252 rattlesnake sightings (including 78 hibernacula) collected since 1978 by Alberta Natural Resources Service personnel, environmental consultants, naturalists and professional biologists. A large data set was also provided by Express Pipeline Ltd. A complete list of these records, which were reduced to a smaller number of unique (township/range) locations for constructing the map, is provided in Appendix 2. Although these sightings are not a complete census of all possible sources, they are thought to provide an accurate indication of the current distribution of the Prairie Rattlesnake in the province. The historic distribution (up to and including 1977; Figure 1) is based on 49 records found in the literature or museum records. Specific details on these records are listed in Appendix 3.

In Alberta, Prairie Rattlesnake populations reach the northern limits of their range (MacArtney and Weichel 1989, McCorquedale 1965). Records prior to 1978 (Figure 1) suggest that the distribution of Prairie Rattlesnakes was formerly greater than is seen currently (Cottonwood Consultants 1986, Pendlebury 1977, Russell and Bauer 1993). These historical records indicate that the range may have extended along 


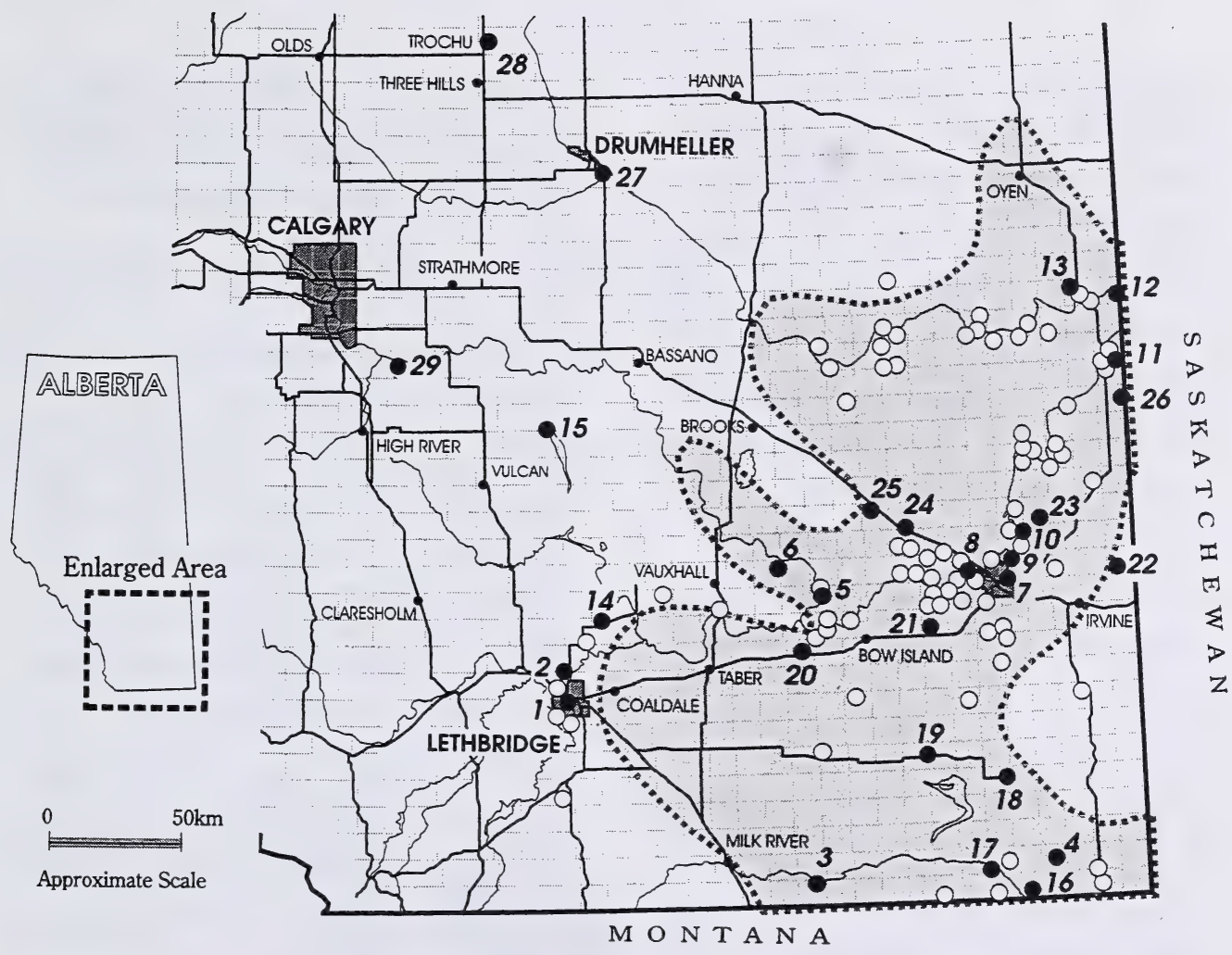

Figure 1. Recent (open circles) and historic (pre-1978; solid circles with numbers) records of Prairie Rattlesnakes in Alberta, and the provincial range of the species as determined by Pendlebury (1977; shaded area). Sources and descriptions for recent and historic records are provided in Appendix 2 and 3.

the Red Deer River to Trochu, and along the Bow River almost to Calgary (Russell and Bauer 1993). However, the current distribution of $\underline{\mathrm{C}}$. $\underline{\mathrm{v}}$. viridis in Alberta (Figure 1) is restricted to the southeastern corner of the province (east of $112^{\circ} 53^{\prime} \mathrm{W}$ and south of $51^{\circ} 22 \mathrm{~N}$; Pendlebury 1977 , Russell and Bauer 1993), and does not appear to have changed appreciably since Prairie Rattlesnake distribution was studied by Pendlebury in 1977 .

In general, the distribution of Prairie
Rattlesnakes appears to be closely associated with major rivers (Cottonwood Consultants 1987, Gannon 1978, Pendlebury 1977). The majority of records from Alberta occur along the South Saskatchewan River drainage (including the South Saskatchewan, Red Deer, Bow, and Oldman Rivers) and the Missouri River drainage which includes the Milk River (Gannon 1978). Away from the river valleys, the relative abundance of $\underline{\mathbf{C}}$. $\underline{\text {. viridis }}$ decreases. 
2. Other Areas. - The distribution of the Western Rattlesnake in North America (Figure 2) ranges from Baja California and north-central Mexico to southern Alberta, southwestern Saskatchewan, and south-central British Columbia, and extends from the Pacific Coast to western Iowa (Behler and King 1979, Russell and Bauer 1993, Stebbins 1985). However, within this area, Western Rattlesnake distribution is quite fragmented (Russell and Bauer 1993).

The Prairie Rattlesnake is the most widely-distributed subspecies of $\underline{\mathrm{C}}$. viridis (Gannon and Secoy 1984). Its range (Figure 2) includes the area from northern Mexico through the central United States (including Arizona, Colorado, Idaho, Iowa, Kansas, Montana, Nebraska, New Mexico, North Dakota, Oklahoma, South Dakota, Texas, and Wyoming) and extends north into southeastern Alberta and southwestern Saskatchewan (Conant 1975, Klauber 1956).

In Saskatchewan, the range of the Prairie Rattlesnake actually consists of two disjunct components. The southern portion is associated with the lower reaches of the Frenchman River south of Val Marie, whereas the northern portion extends from the Alberta-Saskatchewan border along the South Saskatchewan River to a point south of Eatonia (Pendlebury 1977).

The only other subspecies of the Western Rattlesnake in Canada is $\underline{\mathrm{C}}$. $\underline{\mathrm{v}}$. oreganus, which is found in British Columbia. The range of this subspecies is also quite restricted; populations are found only in the south-central regions of the province, primarily in the Thompson and Okanagan basins and in the Nicola Valley (Charland et al. 1993). As with $\underline{\mathrm{C}}$. $\underline{\mathrm{v}}$. viridis in Alberta, the distribution of $\underline{\mathrm{C}} . \underline{\mathrm{y}}$. oreganus in British Columbia appears to be largely associated with major river systems.

\section{POPULATION SIZE AND TRENDS}

1. Alberta. - Attempting to document changes in population size over time is difficult without accurate historical data (Kissner et al. 1996). Although historical information on Prairie Rattlesnake populations is limited, anecdotal reports indicate that numbers have decreased since European settlers arrived in western Canada (MacArtney and Weichel 1989). In Alberta, recent reports on local populations indicate variation between sites. At some localities, populations appear to have remained stable or even increased (one locality), whereas at several sites, snake dens have been destroyed, become inactive, or have experienced substantially reduced numbers (Cottonwood Consultants 1986, 1987). It has been suggested that most dens in Alberta currently contain less than one hundred rattlesnakes, whereas historically, some den sites may have housed several hundred individuals (Cottonwood Consultants 1987).

An increase in Prairie Rattlesnake numbers has occurred in Dinosaur Provincial Park. Pendlebury (1977) indicated that although rattlesnakes were common in the area in 1912, no rattlesnakes were thought to be present when his study was conducted. Starting in 1977, however, several rattlesnakes appeared in the Park, and since that time, a number of snake sightings are reported every year (Cottonwood Consultants 1986). Recently, the number of reports 


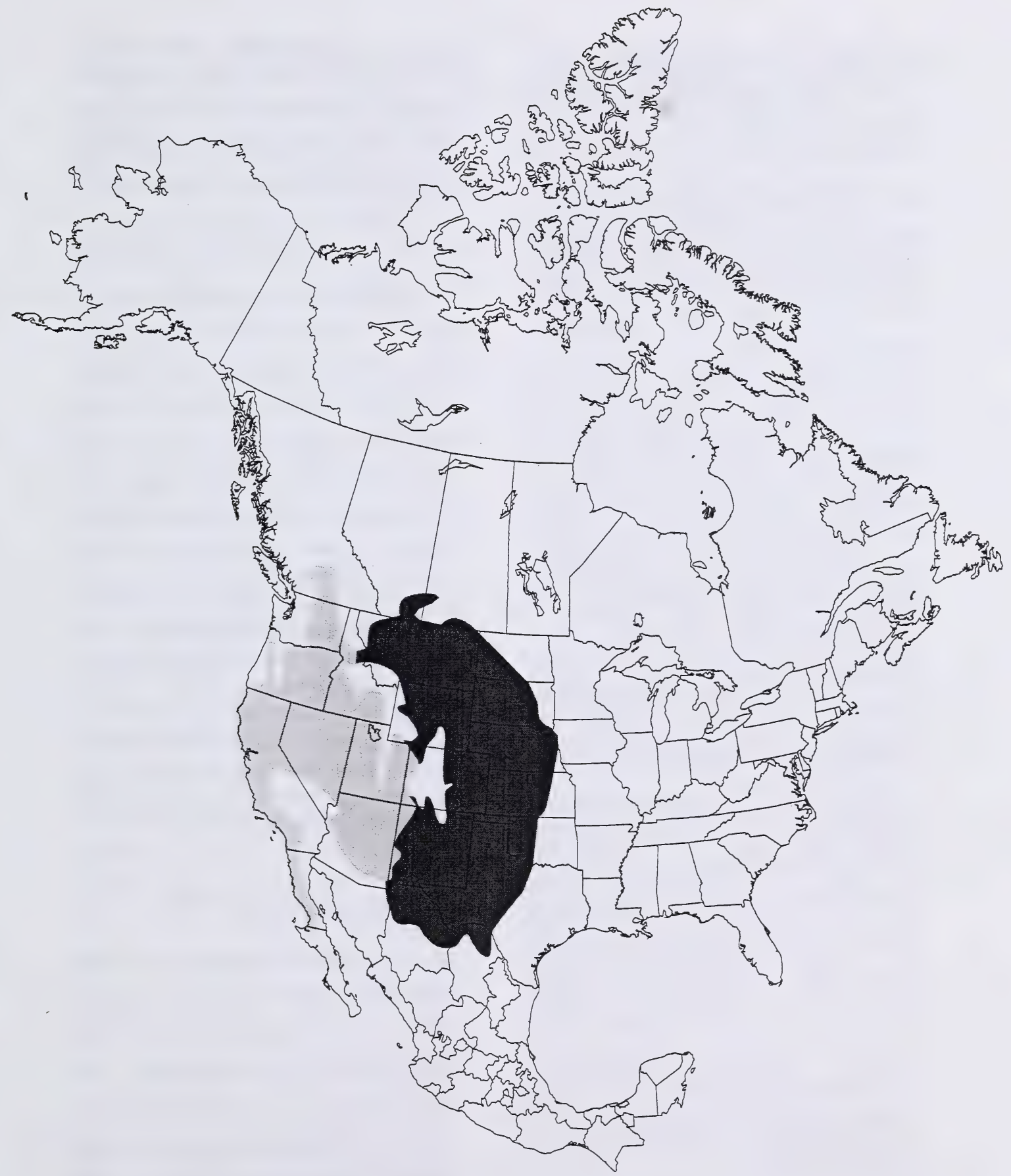

Figure 2. Distribution of the Western Rattlesnake in North America (modified from Stebbins 1985). The dark region represents the distribution of the subspecies Crotalus $\underline{\mathrm{V}}$. viridis, the Prairie Rattlesnake. 
has increased dramatically (34 in 1995, 85 in 1996; Anonymous 1996), and several active den sites have been located (D. Crooks, pers. comm.).

Prairie Rattlesnake populations appear to have experienced recent or long-term declines at a number of sites including Sandy Point (south of Empress), and along the lower Red Deer, Milk, and Oldman Rivers (Cottonwood Consultants 1986, 1987). The number of rattlesnake sightings also dropped from 90 in 1995 to only 31 in 1996 at Writing-on-Stone Provincial Park (R. Ward, pers. comm.). Whether this decrease in observed rattlesnake numbers reflects a decline in local population size is unknown. During a study in 1994-96 at the proposed Suffield National Wildlife Area, 10 rattlesnake dens, and populations estimated to be in the thousands, were observed along the South Saskatchewan River (A. Didiuk, unpubl. data); however, no comparative data is available to determine population trends at these sites.

2. Other Areas. - Extensive population studies have been conducted at several sites in Saskatchewan, and estimates of the provincial population (based on data from 17 to 22 hibernacula) range from 2,000 to 4,500 individuals (MacArtney and Weichel 1989, 1993). In addition, population size estimates for specific den sites in Saskatchewan range from $149 \pm 51$ (Gannon and Secoy 1984) to $313-455$ (Kissner et al. 1996) individuals. It is not known whether these population estimates represent increasing, decreasing, or stable population sizes.

Population trends are also unknown for $\underline{\mathrm{C}}$. v. oreganus populations in British
Columbia (Charland et al. 1993). It has been suggested, however, that numbers have likely been reduced as a result of the extensive development that has occurred within the Western Rattlesnake range in British Columbia (Charland et al. 1993).

Estimates for population sizes of Prairie Rattlesnakes outside of Canada are not available. However, in several states large numbers of rattlesnakes are collected each year during "rattlesnake roundups" (Adams et al. 1994, Warwick et al. 1991). Although these roundups were traditionally held to try to eradicate rattlesnakes from certain areas, the current focus is to collect snakes for commercial uses (Reber and Reber 1994). One estimate of the number of rattlesnakes removed from natural populations each year at these events was between 60,600 and 101,000 individuals (Warwick et al. 1991). Although the number of snakes harvested each year has been relatively stable, an increase in the number of hunters, area covered, and more intrusive methods used to capture rattlesnakes indicate that numbers are in decline (Campbell 1989, in Reber and Reber 1994).

\section{LIMITING FACTORS}

Prairie Rattlesnake populations in Alberta appear to be limited in distribution and number by several factors, including the presence of suitable hibernacula (Cook 1984, Cottonwood Consultants 1986, 1987, Gannon 1978, MacArtney and Weichel 1989, Pendlebury 1977), and the availability of summer foraging areas and birthing rookeries. These habitat requirements, in conjunction with climate and slow population growth, are "natural" 
limiting factors, and may further magnify the impact of human-related influences on Prairie Rattlesnake populations. Human activities that appear to have the greatest influence on Prairie Rattlesnake numbers and distribution include road and pipeline construction, agricultural activities, and intentional persecution.

\section{Intentional Persecution. -} Traditionally, rattlesnakes have been viewed negatively by the public (Halladay 1965). However, recent reports in Alberta indicate that the attitude of the public towards rattlesnakes is improving (Cottonwood Consultants 1987, L. Powell pers. comm.). Rattlesnakes are thought to play an important role in regulating local rodent populations (Cook 1984, Cottonwood Consultants 1987, Russell and Bauer 1993), and reports indicate that some ranchers in Alberta and Saskatchewan are very protective of Prairie Rattlesnakes and their dens because of their perceived role in rodent control (A. Didiuk, unpubl. data). However, intentional killing and den vandalism are still known to occur in western Canada (Cook 1984, Cottonwood Consultants 1987, MacArtney and Weichel 1989, 1993, W. Smith, pers. comm.). Rattlesnake aggregations at hibernacula, as well as their conspicuous behaviour (rattling), increases the vulnerability of this species to malicious acts (Parker and Brown 1974).

Den vandalism is of special concern, as rattlesnakes appear to exhibit high fidelity to den sites, and damage to hibernacula may result in high mortality if rattlesnakes fail to find alternate overwintering locations (Duvall et al. 1985, Kissner et al. 1996). Suitable hibernation sites may be limited even in areas with superficial appearance of abundance. MacArtney et al. (1989) studied thermal dynamics of $\underline{C}$. viridis hibernacula in British Columbia and found that the core temperature of an occupied den was 3 to $5^{\circ} \mathrm{C}$ during the coldest part of the winter, whereas an unoccupied site that appeared to be suitable experienced subzero temperatures which would have been lethal to rattlesnakes.

\section{Roads and Pipeline Construction. -}

Road and pipeline construction, as well as traffic along roadways, also appear to be important sources of mortality for Prairie Rattlesnakes (Cottonwood Consultants 1986, 1987, A. Didiuk, pers. comm., W. Smith, pers. comm.). Furthermore, improvements to roadways, such as paving, may be increasing road mortality in the province by promoting higher vehicle speeds and allowing easier detection of snakes on pavement for those intent on killing snakes (A. Didiuk, pers. comm.). In the past, there was significant mortality of snakes that fell into pipeline trenches, as these excavations were simply filled in after pipelines were laid (E. Ruff, pers. comm.). Today, companies such as Express Pipeline Ltd. have started to monitor and remove rattlesnakes from trenches (R. Lauzon, pers. comm.). This practice should greatly reduce the mortality of rattlesnakes associated with pipeline construction.

3. Agricultural Activities. - A short growing season is characteristic of the semi-arid climate in the mixed grassland region of Alberta (Coupland 1950, 1961). This abbreviated season means that there is relatively little time for rattlesnakes to migrate to and from foraging sites where 
they accumulate reserves for winter hibernation. Availability of suitable foraging sites within reasonable distances from den sites is therefore expected to be of great importance for high-latitude populations such as those in Alberta.

The intensification of agriculture within the range of the Prairie Rattlesnake may be reducing the availability of foraging habitat. For example, approximately $23 \%$ of the uncultivated mixed prairie that existed in 1956 had been plowed under by 1981 , and much of the remaining rangeland has been subjected to increased grazing pressure (Anonymous 1994, Wallis 1987). The quality of remaining native grasslands might also be reduced by rodent-control programs, which reduce numbers of prey available to rattlesnakes (L. Powell, pers. comm.).

Overall, the impacts of anthropogenic influences on populations of Prairie Rattlesnakes are currently not well known (MacArtney and Weichel 1993). It has been suggested, however, that habitat reduction and disturbance through agricultural influences may have contributed significantly to the apparent decrease in Prairie Rattlesnake numbers in Canada (Cottonwood Consultants 1986, MacArtney and Weichel 1989, Pendlebury 1977, Russell and Bauer 1993). Further investigations may reveal whether the same influences are responsible for recent changes in the abundance and distribution of this species in Alberta.

\section{STATUS DESIGNATIONS}

1. Alberta. - Under the 1987 Alberta Wildlife Act, Prairie Rattlesnakes were listed as "non-licence animals" (Alberta
Fish and Wildlife 1989) which can generally be hunted or harvested without a permit. Specific restrictions, however, prevented the sale or live possession of Prairie Rattlesnakes, and hibernacula were offered protection from disturbance between September 1 and April 30 (S. Brechtel, pers. comm.). In January 1997, the legal designation of the Prairie Rattlesnake was changed to "non-game animal". This new designation increased the amount of protection available for this species by making it illegal to kill, possess, buy or sell rattlesnakes in Alberta. Despite these legal regulations, rattlesnakes can still be killed if they pose a threat to individual safety.

One of the first unofficial status designations for the Prairie Rattlesnake in Alberta was assigned by the Alberta Committee on Rare and Endangered Species, which described this species as "locally abundant in southeastern Alberta" (Anonymous 1984). In 1991, the Prairie Rattlesnake was designated as a "Blue-listed" species in Alberta (Alberta Fish and Wildlife 1991), and has retained this status in a recent revision of the provincial color lists (Alberta Wildlife Management Division 1996). As a "Blue-listed" species, the Prairie Rattlesnake "may be at risk" and, although not immediately threatened, the species is thought to be susceptible to habitat disturbance, population decline, or reductions in provincial distribution (Alberta Wildlife Management Division 1996).

Additional protection is also available for wildlife and wildlife habitat located within national and provincial parks, provincial Natural Areas, and Ecological Reserves. 
Prairie Rattlesnake populations are known to exist within Writing-on-Stone Provincial Park, Dinosaur Provincial Park, and the Kennedy Creek/Milk River Canyon Ecological Reserve (Cottonwood Consultants 1986, 1987). In addition, "large" populations have been found within the Canadian Forces Base Suffield (A. Didiuk, pers. comm.), of which 440 $\mathrm{km}^{2}$ has been proposed as a National Wildlife Area (Trottier 1996), and on the federally-owned Onefour Experimental Farm. Increased protection for endangered wildlife is expected to occur with the introduction of the Canadian Endangered Species Protection Act which is currently being reviewed by the House of Commons (Anonymous 1997). Whether the Prairie Rattlesnake will be among the species protected by this act is yet to be determined.

2. Other Areas. - To date, the status of the Western Rattlesnake, or either of its two Canadian subspecies, has not been evaluated by the Committee on the Status of Endangered Wildlife in Canada (COSEWIC; Anonymous 1995, A. Didiuk, pers. comm.). The Prairie Conservation Action Plan, prepared by the World Wildlife Fund, lists the subspecies

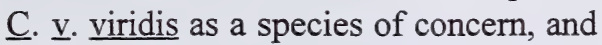
recommends that a status report be prepared (Anonymous 1994). Currently, a status report on the Western Rattlesnake in Alberta, Saskatchewan, and British Columbia is being prepared for COSEWIC by Andy Didiuk and Malcolm MacArtney, and will be completed by the fall of 1997 (A. Didiuk, pers. comm.).

Although $\underline{\text { C. }} \underline{\mathrm{v}}$. viridis has not been assigned a formal status in Saskatchewan (W. Harris, pers. comm.), unofficial reports list the Prairie Rattlesnake as a "threatened" species (MacArtney and Weichel 1993, Secoy 1987). Legal protection available for this species under the 1988 Saskatchewan Wildlife Act prohibits unauthorized killing and possession of these snakes. However, this legislation does not provide protection for rattlesnake hibernacula (MacArtney and Weichel 1989, 1993). Fortunately, a number of known hibernacula in Saskatchewan are situated such that they are protected under the Critical Wildlife Habitat Protection Act, or are within the proposed boundaries of Grasslands National Park (MacArtney and Weichel $1989,1993)$. Since July 1996, an informal policy has been adopted within the grassland ecosystem of Saskatchewan which restricts activity (e.g., oil and gas projects) around hibernacula and birthing areas of Prairie Rattlesnakes (W. Harris, pers. comm.).

In British Columbia, $\underline{\mathrm{C}}$. $\underline{\text {. oreganus is }}$ "Blue-listed" as a vulnerable or sensitive species because of its limited distribution in the province, and its vulnerability to direct killing and habitat loss (Blood 1993, Harding and McCullum 1994). Rattlesnakes in British Columbia are protected from "collection and killing, except where they are a menace" under their provincial Wildlife Act (Blood 1993, Charland et al. 1993).

In Montana, rattlesnakes are classified as a "non-game species", but unlike in Alberta, this status does not offer any protection (D. Genter, pers. comm.). In fact, the Western Rattlesnake apparently does not have protected status anywhere in the United States, as evidenced by the yearly "rattlesnake roundups" that occur in 
several states (Adams et al. 1994, Warwick et al. 1991).

\section{RECENT MANAGEMENT IN ALBERTA}

In general, management of rattlesnakes in Alberta currently consists of relocation by local authorities when these snakes are encountered by the public (R. Hugill, R. Morrison, P. Shields, pers. comm.). However, there are a number of initiatives in the province that are addressing management issues, or that are collecting and disseminating information that should lead to improved management of Prairie Rattlesnakes in the future.

\section{Dinosaur Provincial Park. - At} Dinosaur Provincial Park there continues to be an increase in rattlesnake sightings within the facility zone area. With over 60,000 visitors to the park each year, there is significant potential for human confrontations with snakes, and therefore public safety and the protection of rattlesnake populations have become a primary management concern. A five-year commitment has recently been made between Dinosaur Provincial Park, the Canadian Wildlife Service and Operation Grassland Community to conduct a radiotelemetry and tagging program to learn more about the natural history of Prairie Rattlesnakes within the park (Anonymous 1996). The study, which yielded a large amount of baseline data during its pilot year in 1996, should allow for informed management decisions in the future (Anonymous 1996).

\section{Suffield National Wildlife Area. -} Research on Prairie Rattlesnakes at the proposed Suffield National Wildlife Area includes radio telemetry and the use of drift fencing to monitor rattlesnakes moving to and from dens sites in the spring and fall (A. Didiuk, pers. comm.). Additional data has been collected at dens to assess population size and structure, reproductive status, and survival (Trottier and Didiuk 1995, A. Didiuk, pers. comm.). This study has been ongoing for the past three years, and continued monitoring of dens is expected to occur in upcoming years.

3. Medicine Hat Area. - Another multiyear rattlesnake study has been initiated at a site near Medicine Hat (L. Powell, pers. comm.). The focus of this research is on population dynamics and movements of rattlesnakes in a multi-use landscape. The study area is located on the east side of the South Saskatchewan River, north of Medicine Hat and south of the Koomati section of Suffield Military Reserve in an area exposed to a variety of anthropogenic activities. Activities such as gas extraction, ranching, farming, and hunting all occur within this region, and drift fencing, radio telemetry, and mark-recapture methods will be used to collect data on the effect of these land-use practices on rattlesnake populations. Preliminary data is currently being collected on den-site characteristics; data loggers are being used to collect thermal data, and Alberta Environmental Protection (Corporate Management Service) in Lethbridge has been enlisted to apply geographical information systems and remote sensing analysis to examine landscape characteristics of known den sites, and to identify other potential den locations in the area (L. Powell and D. Eslinger, pers. comm.). 
4. Alberta Snake Hibernaculum

Inventory. - This program, initiated in 1996 by the Status and Surveys Branch of Alberta Natural Resources Service, maintains a central database of information on the location, features and longevity of hibernacula occupied by all snake species in Alberta. This information, which is obtained from interested landowners and naturalists, is intended to increase our understanding of rattlesnake distribution and relative abundance within the province (D. Ryerson, pers. comm.).

\section{Operation Grassland Community. -} Operation Grassland Community (OGC), a multi-species habitat retention program of the Alberta Fish and Game Association (AFGA), added amphibians and reptiles to their list of profile species in 1996. Education and awareness may be instrumental in reducing the intentional persecution endured by Prairie Rattlesnakes, and OGC uses media events, the internet and displays to educate the public on the importance of snakes and their overwintering sites to the grassland community. Furthermore, OGC represents the AFGA on the Express Pipeline Environmental Advisory Committee. Through the efforts of this committee, a large data set of Prairie Rattlesnake localities has been collected.

The comparative data that will be provided by current research projects is extremely important in evaluating variation between local populations, which until now has been notably lacking for Alberta populations. Also, the absence of long-term studies on Alberta rattlesnake populations in the past has made accurate analysis of population trends impossible.
Long-term population studies, such as those currently underway in the province, will greatly improve our understanding of populations sizes and trends within the province. In addition, increased public awareness through initiatives such as the Alberta Snake Hibernacula Inventory and those put forth by Operation Grassland Community will hopefully improve public understanding and appreciation of Prairie Rattlesnakes.

\section{SYNTHESIS}

Limited knowledge of historic distribution and population trends, as well as a lack of sufficient baseline data on species biology, has made the assignment of herpetofauna to status levels extremely difficult (Secoy 1987). From the sparse historic data that are available, it appears that Prairie Rattlesnake distribution experienced some decrease in Alberta prior to 1978. However, comparison of current distribution with that found by Pendlebury (1977), reveals that relatively little change in rattlesnake distribution has occurred in the last 20 years. No comprehensive or reliable data are currently available to define the relative abundance or distribution within this range. However, available site records suggest that the highest populations occur in or near major river valleys within the species' provincial range.

Prairie Rattlesnake numbers are thought to be increasing at only one site, but declining at a large number of other localities in Alberta. Unfortunately, these population trends are based solely on anecdotal data, and more intensive study of Alberta rattlesnake populations is required before these trends can be 
accurately assessed.

If the apparent trends are accurate, there is considerable cause for concern, as the low recruitment and reproductive capacity of this species means an extended time frame may be required for populations to recover. In addition, although the Prairie Rattlesnake is legally protected from killing or destruction of hibernacula in the province, this species remains at risk because the aggregation of rattlesnakes in spring and fall, as well as the high fidelity to den sites, makes this species vulnerable to rapid and severe decreases in population size if such events do occur.
Continued protection of the Prairie Rattlesnake and its hibernacula is therefore critical to the survival of this species. Currently, hibernacula are protected from September 1 to April 30, however, as den sites in Alberta may be occupied by significant numbers of rattlesnakes from the middle of August until June 15 (A. Didiuk, pers. comm.), an increase in protection for den sites should be considered. Also, although reports of malicious acts towards Prairie Rattlesnakes appear to be decreasing, the intentional persecution of these snakes may be further reduced through education programs aimed at improving the public regard for this species. 


\section{LITERATURE CITED}

Adams, C. E., J. K. Thomas, K. J. Strnadel, and S. L. Lester. 1994. Texas rattlesnake roundups: Implications of unregulated commercial use of wildlife. Wild. Soc. Bull. 22: 324-330.

Alberta Fish and Wildlife. 1985. A policy for the management of threatened wildlife in Alberta. Alberta Fish and Wildlife Division, Edmonton, AB. 34 pp.

Alberta Fish and Wildlife. 1989. Wildlife in Alberta: a new definition. Alberta Fish and Wildlife, Edmonton, $\mathrm{AB}, 12$ pp.

Alberta Fish and Wildlife. 1991. The status of Alberta wildlife. Alberta Fish and Wildlife, Edmonton, AB. 49 pp.

Alberta Wildlife Management Division. 1996. The status of Alberta wildlife. Alberta Natural Resources Service, Edmonton; AB. 44 pp.

Alderidge, R. D. 1993. Male reproductive anatomy and seasonal occurrence of mating and combat behaviour of the rattlesnake, Crotalus v. viridis. J. Herpetol. 27: 481-484.

Anonymous. 1984. Status of the fish and wildlife resource in Alberta. Alberta Fish and Wildlife, Edmonton, AB. 123 pp.

Anonymous. 1994. Prairie Conservation Action Plan, 1989-1994. World Wildlife Fund Canada, Toronto, ON. $38 \mathrm{pp}$.
Anonymous. 1995. Canadian species at risk, 1995. Committee on the Status of Endangered Wildlife in Canada, Ottawa, ON.

Anonymous. 1996. Dinosaur Provincial Park: the snake project. Unpublished MS, Dinosaur Provincial Park, AB. $23 \mathrm{pp}$.

Anonymous. 1997. Will Canadian politicians help stop the extinction clock? In Working for wildlife, winter 1996/1997. World Wildlife Fund Canada, Toronto, ON.

Behler, J. L., and F. W. King. 1979. The Audubon Society field guide to North American reptiles and amphibians. Alfred A. Knopf, New York, NY. 720 pp.

Blood, D. A. 1993. Western Rattlesnake. B. C. Ministry of Environment, Lands and Parks, Victoria, BC.

Charland, M. B. 1989. Size and winter survivorship in neonatal Western Rattlesnakes (Crotalus viridis). Can. J. Zool. 67: 1620-1625.

Charland, M. B., and P. T. Gregory. 1990. The influence of female reproductive status on thermoregulation in a viviparous snake, Crotalus viridis. Copeia 4: 1089-1098.

Charland, M. B., K. J. Nelson, and P. T. Gregory. 1993. Status of the Northern Pacific Rattlesnake in British Columbia. B. C. Ministry of Environment, Wildlife Branch, Working Wildlife Report No. WR-54. $18 \mathrm{pp}$. 
Conant, R. 1975. A field guide to reptiles and amphibians of eastern and central North America. Houghton Mifflin Company, Boston, MA. 429 pp.

Cook, F. R. 1984. Introduction to Canadian amphibians and reptiles. National Museum of Natural Sciences, National Museums of Canada. Ottawa, ON. 200 pp.

COSEWIC. 1996. Canadian species at risk. Committee on the Status of Endangered Wildlife in Canada, Ottawa, ON. 18 pp.

Cottonwood Consultants. 1987. Alberta snake hibernacula survey. Unpubl. rept. for World Wildlife Fund Canada, Wild West Program. 50 pp.

Cottonwood Consultants. 1986. An overview of reptiles and amphibians in Alberta's Grassland and Parkland Natural Regions. Unpubl. rept. for World Wildlife Fund Canada, Wild West Program. 53 pp.

Coupland, R. T. 1950. Ecology of mixed prairie in Canada. Ecol. Monogr. 20: 271-315.

Coupland, R. T. 1961. A reconsideration of grassland classification in the northern Great Plains of North America. J. Ecol. 49: 135-167.

Duvall, D., M. B. King, and K. J. Gutzwiller. 1985. Behavioral ecology and ethology of the Prairie Rattlesnake. Natl. Geogr. Res. 1: 80-111.

Duvall, D., M. J. Goode, W. K. Hayes, J.
K. Leonhardt, and D. G. Brown. 1990. Prairie Rattlesnakes vernal migration: field experimental analysis and survival value. Natl. Geogr. Res. 6: 457-469.

Fitch, H. S. 1949. Study of snake populations in central California. Am. Midl. Nat. 41: 513-579.

Fowler, R. L. 1934. Some amphibian and reptiles of the district around High River, Alberta, 1933. Can. FieldNatur. 48:139-140.

Gannon, V. P. J. 1978. Factors limiting the distribution of the Prairie Rattlesnake. Blue Jay 36: 142-144.

Gannon, V. P. J., and D. M. Secoy. 1984. Growth and reproductive rates of a northern population of the Prairie Rattlesnake, Crotalus viridis viridis. J. Herpetol. 18: 13-19.

Gannon, V. P. J., and D. M. Secoy. 1985. Seasonal and daily activity patterns in a Canadian population of the Prairie Rattlesnake, Crotalus viridis viridis. Can. J. Zool. 63: 86-91.

Graves, B. M., D. Duvall, M. B. King, S . L. Lindstedt, and W. A. Gern. 1986. Initial den location by neonatal Prairie Rattlesnakes: functions, causes and natural history in chemical ecology. Proceedings of the International Symposium in Chemical Signals in Vertebrates Vol. 4: 285-304.

Halladay, I. R. 1965. Recent biota of the Cypress Hills Plateau: A general survey of the natural history. Pp. 37-54 in Alberta Society of Petroleum 
Geologists 13th Annual Field Conference Guide, Part 1 (R. L. Zell ed).

Harding, L. E., and E. McCullum. 1994. Biodiversity in British Columbia: Our changing environment. Environment Canada. Canadian Wildlife Service. Pacific and Yukon Region, Vancouver, BC. 426 pp.

Holycross, A. T. 1995. Crotalus viridis (Western Rattlesnake). Phenology. Herptetol. Rev. 26: 37-38.

Jacob, J. S., and C. W. Painter. 1980. Overwintering thermal ecology of Crotalus viridis in the north-central plains of New Mexico. Copeia 4: 799-805.

Keenlyne, K. D. 1972. Sexual differences in feeding habits of Crotalus horridus horridus. J. Herpetol. 6: 234-237.

Kissner, K. J., D. M. Secoy, and M. R. Forbes. 1996. Assessing population size and den use of Prairie Rattlesnake (Crotalus viridis viridis) in southern Saskatchewan. Grassland National Park annual report, vol. 1: 27-34.

Klauber, L. M. 1956. Rattlesnakes: Their habits, life histories, and influence on mankind. University of California Press, Berkley, CA. 708 pp.

Lewin, V. 1963. The herpetofauna of southeastern Alberta. Can. Field-Nat. 77: 203-214.

Logier, E. B. S., and G. C. Toner. 1961. Checklist of the amphibians and reptiles of Canada and Alaska. The
Royal Ontario Museum, Toronto, ON. $93 \mathrm{pp}$.

MacArtney, J. M., P. T. Gregory, and M. B. Charland. 1990. Growth and sexual maturity of the Western Rattlesnake, Crotalus viridis, in British Columbia. Copeia 2: 528-542.

MacArtney, J. M., K. W. Lausen, and P. T. Gregory. 1989. Body temperature and movements of hibernating snakes (Crotalus and Thamnophis) and thermal gradients of natural hibernacula. Can. J. Zool. 67: 108-114.

MacArtney, M., and B. Weichel. 1989. Prairie Rattlesnake survey and management plan. Blue Jay News 82: 7-8.

MacArtney, M., and B. Weichel. 1993. Status of the Prairie Rattlesnake and the eastern Yellow-bellied Racer in Saskatchewan. Pp. 291-299 in Proceedings of the third prairie conservation and endangered species workshop (G. L. Holroyd, H. L. Dickson, M. Regnier, and H. C. Smith, eds.). Prov. Mus. Alberta Nat. Hist. Occ. Paper No. 19, Edmonton, AB. $384 \mathrm{pp}$.

McCorquedale, B. 1965. Some particular aspects of the biota of the Cypress Hills. Pp. 55-65 in Alberta Society of Petroleum Geologists 13th Annual Field Conference Guide, Part 1 (R. L. Zell, ed.).

National Research Council. 1995. Science and the Endangered Species Act. National Academy Press, 
Washington, DC. 271 pp.

Parker, W. S., and W. S. Brown. 1974. Mortality and weight changes of Great Basin rattlesnakes (Crotalus viridis) at a hibernaculum in Northern Utah. Herpetologica 30: 234-239.

Pendlebury, G. B. 1977. Distribution and abundance of the Prairie Rattlesnake, Crotalus viridis viridis, in Canada. Can. Field-Nat. 91: 122-129.

Reber, D. L., and A. S. Reber. 1994. Position paper regarding rattlesnake roundups. Unpublished MS, Kansas Herpetological Society. 17 pp.

Reichel, J., and D. Flath. 1995. Identification of Montana's amphibians and reptiles. Montana Outdoors 36: 15-34.

Russell, A. P., and A. M. Bauer. 1993.

The amphibians and reptiles of Alberta. University of Calgary Press, Calgary, AB. 264 pp.

Secoy, D. M. 1987. Status report on the reptiles and amphibians of Saskatchewan. Pp. 139-141 in Endangered species in the prairie provinces (G. L. Holroyd, W. B. McGillivray, P. H. R. Stepney, D. M. Ealey, G. C. Trottier, and K. E. Eberhart, eds.) . Prov. Mus. Alberta Nat. Hist. Occ. Paper No. 9, Edmonton, AB. 367 pp.
Stark, M. A. 1985. A simple technique for trapping Prairie Rattlesnakes during spring emergence. Herpetol. Rev. 16: 76-77.

Stebbins, R. C. 1985. A field guide to western reptiles and amphibians. Houghton Mifflin Company, Boston, MA. 336 pp.

Trottier, G., and A. Didiuk. 1995. 1994 progress summary - reptiles/ amphibians of Suffield NWA. Unpublished MS, Canadian Wildlife Service, Saskatoon, SK. 16 pp.

Trottier, G. 1996. Suffield National Wildlife Area: ecological inventory. Pp. 169 in Proceedings of the fourth prairie conservation and endangered species workshop (W. D. Willms and J. F. Dormaar, eds.). Prov. Mus. Alberta Nat. Hist. Occ. Paper No. 23, Edmonton, AB. 337 pp.

Wallis, C. 1987. Critical, threatened, and endangered habitats in Alberta. Pp. 49-63 in Endangered species in the prairie provinces (G. L. Holroyd, W. B. McGillivray, P. H. R. Stepney, D. M. Ealey, G. C. Trottier, and K. E. Eberhart, eds.). Prov. Mus. Alberta Nat. Hist. Occ. Paper No. 9, Edmonton, AB. 367 pp.

Warwick, C., C. Steedman, and T. Halford. 1991. Rattlesnake collection drives-their implications for species and environmental conservation. Oryx 25: $39-44$. 
APPENDIX 1. Definitions of selected legal and protective designations.

\section{A. Status of Alberta Wildlife color lists (after Alberta Wildlife Management Division 1996)}

\begin{tabular}{|l|l|}
\hline Red & $\begin{array}{l}\text { Current knowledge suggests that these species are at risk. These species have declined, or are } \\
\text { in immediate danger of declining, to nonviable population size }\end{array}$ \\
\hline Blue & $\begin{array}{l}\text { Current knowledge suggests that these species may be at risk. These species have undergone } \\
\text { non-cyclical declines in population or habitat, or reductions in provincial distribution }\end{array}$ \\
\hline Yellow & $\begin{array}{l}\text { Species that are not currently at risk, but may require special management to address concerns } \\
\text { related to naturally low populations, limited provincial distributions, or demographic/life } \\
\text { history features that make them vulnerable to human-related changes in the environment }\end{array}$ \\
\hline Green & $\begin{array}{l}\text { Species not considered to be at risk. Populations are stable and key habitats are generally } \\
\text { secure }\end{array}$ \\
\hline Undetermined & Species not known to be at risk, but insufficient information is available to determine status \\
\hline
\end{tabular}

\section{B. Alberta Wildlife Act}

Species designated as "endangered" under the Alberta Wildlife Act include those defined as "endangered" or "threatened" by A Policy for the Management of Threatened Wildlife in Alberta (Alberta Fish and Wildlife 1985):

\begin{tabular}{|l|l|}
\hline Endangered & A species whose present existence in Alberta is in danger of extinction within the next decade \\
\hline Threatened & $\begin{array}{l}\text { A species that is likely to become endangered if the factors causing its vulnerability are not } \\
\text { reversed }\end{array}$ \\
\hline
\end{tabular}

\section{Committee on the Status of Endangered Wildlife in Canada (after COSEWIC 1996)}

\begin{tabular}{|l|l|}
\hline Extirpated & A species no longer existing in the wild in Canada, but occurring elsewhere \\
\hline Endangered & A species facing imminent extirpation or extinction \\
\hline Threatened & A species likely to become endangered if limiting factors are not reversed \\
\hline Vulnerable & $\begin{array}{l}\text { A species of special concern because of characteristics that make it particularly sensitive to } \\
\text { human activities or natural events }\end{array}$ \\
\hline Not at Risk & A species that has been evaluated and found to be not at risk \\
\hline Indeterminate & A species for which there is insufficient scientific information to support status designation \\
\hline
\end{tabular}

\section{United States Endangered Species Act (after National Research Council 1995)}

\begin{tabular}{|l|l|}
\hline Endangered & Any species which is in danger of extinction throughout all or a significant portion of its range \\
\hline Threatened & $\begin{array}{l}\text { Any species which is likely to become an endangered species within the foreseeable future } \\
\text { throughout all or a significant portion of its range }\end{array}$ \\
\hline
\end{tabular}


APPENDIX 2. Recent (1978 or later) records of the Prairie Rattlesnake in Alberta. Georeferences correspond to open circles plotted in Figure 1.

\begin{tabular}{|c|c|c|c|c|}
\hline Date & Georeference(1) & Site Description & \# Observed(2) & Source(3) \\
\hline 1987 & $\mathrm{~T} 8, \mathrm{R} 22$ & sensitive information(4) & Den & Cottonwood (1987) \\
\hline Apr. $1983-84$ & $\mathrm{~T} 8, \mathrm{R} 22$ & sensitive information(4) & 5 Dens & Stark (1985) \\
\hline 1996 & $\mathrm{~T} 21, \mathrm{R} 8$ & Paradise Canyon, Lethbridge & $\mathrm{n} / \mathrm{a}$ & E. Saunders \\
\hline July 16,1996 & $\mathrm{~T} 21, \mathrm{R} 8$ & sensitive information(4) & Den & Leth. F\&W \\
\hline 1996 & $\mathrm{~T} 21, \mathrm{R} 8$ & Popson Park, Lethbridge & $\mathrm{n} / \mathrm{a}$ & E. Saunders \\
\hline Aug, 1996 & $\mathrm{~T} 21, \mathrm{R} 8$ & Popson Park, Lethbridge & $\mathrm{n} / \mathrm{a}$ & Leth. Nat Society \\
\hline May, 1992 & $\mathrm{~T} 21, \mathrm{R} 8$ & Popson Park, Lethbridge & $\mathrm{n} / \mathrm{a}$ & Leth. Nat Society \\
\hline no date & $\mathrm{T} 21, \mathrm{R} 8$ & St. Mary River near Junction of Oldman River & $\mathrm{n} / \mathrm{a}$ & Leth. Nat Society \\
\hline July 10,1996 & $\mathrm{~T} 22, \mathrm{R} 8$ & Lethbridge & 2 & Leth. F\&W \\
\hline July 12,1996 & $\mathrm{~T} 22, \mathrm{R} 8$ & Lethbridge & 2 & Leth. F\&W \\
\hline Aug 29, 1996 & $\mathrm{~T} 22, \mathrm{R} 8$ & sensitive information(4) & Den & Leth. F\&W \\
\hline June 29, 1996 & $\mathrm{~T} 22, \mathrm{R} 9$ & Near Lethbridge, Bridge View Campground along Hwy 3 & 1 & Leth. F\&W \\
\hline 1996 & $\mathrm{~T} 22, \mathrm{R} 9$ & $\begin{array}{l}\text { N \& S of Hwy } 3 \text { between Oldman R. \& Bridge Dr., W of } \\
\text { Lethbridge }\end{array}$ & $\mathrm{n} / \mathbf{a}$ & E. Saunders \\
\hline 1996 & $\mathrm{~T} 22, \mathrm{R} 10$ & N of Lethbridge between Diamond City and river & $\mathrm{n} / \mathrm{a}$ & E. Saunders \\
\hline 1995 & $\mathrm{~T} 21, \mathrm{R} 10$ & E of Picture Butte & 1 & A. Lane \\
\hline May 16,1995 & T12,R18 & UTM 0400700,5540200 & 5 & R.L/AXYS/Ex \\
\hline May 16, 1995 & $\mathrm{~T} 12, \mathrm{R} 18$ & UTM 0400700,5540100 & 2 & R.L/AXYS/Ex \\
\hline 1996 & $\mathrm{~T} 1, \mathrm{R} 13$ & sensitive information(4) & Den & R. Ward \\
\hline Oct, 1995 & $\mathrm{~T} 1, \mathrm{R} 13$ & sensitive information(4) & Den & Leth. Nat Society \\
\hline July, 1995 & $\mathrm{~T} 1, \mathrm{R} 13$ & Writing-on-Stone Prov. Park & $\mathrm{n} / \mathrm{a}$ & Leth. Nat Society \\
\hline 1987 & $\mathrm{~T} 1, \mathrm{R} 13$ & sensitive information(4) & Den & Cottonwood (1987) \\
\hline 1987 & $\mathrm{~T} 1, \mathrm{R} 13$ & sensitive information(4) & Maybe 2 Dens & Cottonwood (1987) \\
\hline 1987 & $\mathrm{~T} 1, \mathrm{R} 13$ & sensitive information(4) & Den & Cottonwood (1987) \\
\hline 1979-83 & $\mathrm{T} 2, \mathrm{R} 4$ & Onefour & numerous & L. Powell \\
\hline 1987 & $\mathrm{~T} 1, \mathrm{R} 8$ & sensitive information(4) & Den & Cottonwood (1987) \\
\hline 1996 & $\mathrm{~T} 1, \mathrm{R} 6$ & sensitive information(4) & Den & W. Smith \\
\hline $1979-83$ & $\mathrm{~T} 2, \mathrm{R} 6$ & Comrey & numerous & L. Powell \\
\hline May 30, 1995 & T3,R6 & UTM 0519098, 5447141 & 1 & R.L/AXYS/Ex \\
\hline July 19,1980 & $\mathrm{~T} 1, \mathrm{R} 2$ & Hwy 48 , approx. $3.2 \mathrm{~km} \mathrm{~N}$ of Wildhorse & 1 & NMC (No. 20625) \\
\hline June 21, 1996 & $\mathrm{~T} 1, \mathrm{R} 2$ & UTM 0554735,5431304 & 1 & R.L/AXYS/Ex \\
\hline July 16,1996 & $\mathrm{~T} 2, \mathrm{R} 2$ & UTM 0553000,5438200 & 1 & R.L/AXYS/Ex \\
\hline June 26,1995 & $\mathrm{~T} 2, \mathrm{R} 3$ & UTM 0550170,5503840 & 2 & R.L/AXYS/Ex \\
\hline Sept, 1996 & $\mathrm{~T} 6, \mathrm{R} 12$ & sensitive information(4) & Den & ASHI \\
\hline May 22, 1981 & $\mathrm{~T} 8, \mathrm{R} 15$ & 3mi. S 7mi. E. Taber & 2 & UAMR \\
\hline 1987 & $\mathrm{~T} 8, \mathrm{R} 11$ & sensitive information(4) & Den & Cottonwood (1987) \\
\hline July, 1994 & $\mathrm{~T} 8, \mathrm{R} 7$ & Red Rock Coulee Natural Area & $\mathrm{n} / \mathrm{a}$ & Leth. Nat Society \\
\hline 1987 & $\mathrm{~T} 8, \mathrm{R} 7$ & sensitive information(4) & 2 Dens & Cottonwood (1987) \\
\hline June 25,1995 & T9,R6 & UTM 0521200,5512900 & 1 & R.L/AXYS/EX \\
\hline 1987 & $\mathrm{~T} 12, \mathrm{R} 16$ & sensitive information(4) & 3 Dens & Cottonwood (1987) \\
\hline 1987 & $\mathrm{~T} 11, \mathrm{R} 12$ & sensitive information(4) & Den & Cottonwood (1987) \\
\hline 1987 & $\mathrm{~T} 11, \mathrm{R} 12$ & sensitive information(4) & Den & Cottonwood (1987) \\
\hline Aug. 13,1980 & $\mathrm{~T} 11, \mathrm{R} 12$ & $4 \mathrm{mi} . \mathrm{N}, 5 \mathrm{mi}$. W Bow Island & 4 & UAMR \\
\hline 1994-95 & T11,R11 & NW of Bow Island, N Bank of the S. Saskatchewan R. & numerous & J. James \\
\hline $1979-83$ & T11,R11 & NW of Bow Island, N Bank of the S. Saskatchewan R. & numerous & L. Powell \\
\hline 1987 & $\mathrm{~T} 12, \mathrm{R} 12$ & sensitive information(4) & Den & Cottonwood (1987) \\
\hline
\end{tabular}




\begin{tabular}{|c|c|c|c|c|}
\hline 1987 & $\mathrm{~T} 12, \mathrm{R} 12$ & sensitive information(4) & Den? & Cottonwood (1987) \\
\hline no date-recent & $\mathrm{T} 13, \mathrm{R} 13$ & Hayes, near Medicine Hat & $\mathrm{n} / \mathrm{a}$ & A. Lane \\
\hline 1987 & $\mathrm{~T} 12, \mathrm{R} 8$ & sensitive information(4) & Den & Cottonwood (1987) \\
\hline $1979-83$ & $\mathrm{~T} 12, \mathrm{R} 8$ & NE of Medicine Hat, E bank of the S. Saskatchewan R. & numerous & L. Powell \\
\hline May 16,1995 & $\mathrm{~T} 12, \mathrm{R} 8$ & UTM 0501800,5538400 & 1 & R.L/AXYS/EX \\
\hline May 16,1995 & $\mathrm{~T} 12, \mathrm{R} 8$ & UTM 0501800,5538400 & 1 & R.L/AXYS/EX \\
\hline May 16,1995 & $\mathrm{~T} 12, \mathrm{R} 8$ & UTM 0501642,5538361 & 1 & R.L/AXYS/EX \\
\hline May 16,1995 & $\mathrm{~T} 12, \mathrm{R} 8$ & UTM 0501800,5538300 & 1 & R.L/AXYS/EX \\
\hline May 16,1995 & $\mathrm{~T} 12, \mathrm{R} 8$ & UTM 0501600,5538300 & 4 & R.L/AXYS/Ex \\
\hline May 16,1995 & $\mathrm{~T} 12, \mathrm{R} 8$ & UTM 0501800,5538300 & 1 & R.L/AXYS/EX \\
\hline May 16,1995 & $\mathrm{~T} 12, \mathrm{R} 8$ & UTM 0501600,5538300 & 4 & R.L/AXYS/EX \\
\hline May 16,1995 & $\mathrm{~T} 12, \mathrm{R} 8$ & UTM 0501800,5538300 & 1 & R.L/AXYS/Ex \\
\hline May 16,1995 & $\mathrm{~T} 12, \mathrm{R} 8$ & UTM 0501700,5538300 & 1 & R.L/AXYS/Ex \\
\hline June 26, 1995 & $\mathrm{~T} 12, \mathrm{R} 8$ & UTM 0501642,5538361 & 1 & R.L/AXYS/EX \\
\hline June 26, 1995 & $\mathrm{~T} 12, \mathrm{R} 8$ & UTM 0501400,5538300 & 1 & R.L/AXYS/EX \\
\hline May 21,1996 & $\mathrm{~T} 12, \mathrm{R} 8$ & UTM 0501600,5538300 & 1 & R.L/AXYS/Ex \\
\hline June 14,1996 & $\mathrm{~T} 12, \mathrm{R} 8$ & UTM 0501600,5538300 & 3 & R.L/AXYS/Ex \\
\hline June 15,1996 & $\mathrm{~T} 12, \mathrm{R} 8$ & UTM 0499600,5541900 & 1 & R.L/AXYS/Ex \\
\hline Sept 8, 1996 & $\mathrm{~T} 12, \mathrm{R} 8$ & UTM 0502726,5537304 & 1 & R.L/AXYS/Ex \\
\hline Sept 9,1996 & $\mathrm{~T} 12, \mathrm{R} 8$ & UTM 0501500,5538500 & 1 & R.L/AXYS/EX \\
\hline Sept 12, 1996 & $\mathrm{~T} 12, \mathrm{R} 8$ & UTM 0502000,5537300 & 1 & R.L/AXYS/EX \\
\hline Sept 14,1996 & $\mathrm{~T} 12, \mathrm{R} 8$ & UTM 0501985,5537414 & 1 & R.L/AXYS/EX \\
\hline Sept 27,1996 & $\mathrm{~T} 12, \mathrm{R} 8$ & UTM 0501300,5538250 & 1 & R.L/AXYS/Ex \\
\hline Sept 27, 1996 & $\mathrm{~T} 12, \mathrm{R} 8$ & UTM 0502200,5537300 & 1 & R.L/AXYS/EX \\
\hline Sept 27,1996 & $\mathrm{~T} 12, \mathrm{R} 8$ & UTM 0501250,5538350 & 1 & R.L/AXYS/EX \\
\hline Sept 29,1996 & $\mathrm{~T} 12, \mathrm{R} 8$ & UTM 0501500,5538600 & 1 & R.L/AXYS/EX \\
\hline Oct 3,1996 & $\mathrm{~T} 12, \mathrm{R} 8$ & UTM 0501600,5538600 & 1 & R.L/AXYS/EX \\
\hline Oct 8, 1996 & $\mathrm{~T} 12, \mathrm{R} 8$ & UTM 0501662, 5538333 & 1 & R.L/AXYS/Ex \\
\hline Oct 8,1996 & $\mathrm{~T} 12, \mathrm{R} 8$ & UTM 0501662,5538353 & 1 & R.L/AXYS/Ex \\
\hline Oct 23,1996 & $\mathrm{~T} 12, \mathrm{R} 8$ & UTM 0501500,5538550 & 1 & R.L/AXYS/EX \\
\hline Sept 12,1996 & $\mathrm{~T} 12, \mathrm{R} 7$ & UTM 0503696,5537468 & 1 & R.L/AXYS/EX \\
\hline Sept 13,1996 & $\mathrm{~T} 12, \mathrm{R} 8$ & UTM 0500159,5539970 & 1 & R.L/AXYS/EX \\
\hline Aug 29, 1996 & $\mathrm{~T} 12, \mathrm{R} 8$ & UTM 0499929,5538287 & 1 & R.L/AXYS/EX \\
\hline Sept 11, 1996 & $\mathrm{~T} 12, \mathrm{R} 8$ & UTM 0501500,5538500 & 1 & R.L/AXYS/EX \\
\hline Sept 12,1996 & $\mathrm{~T} 12, \mathrm{R} 9$ & UTM 0485634,5550285 & 1 & R.L/AXYS/EX \\
\hline Sept 7, 1996 & $\mathrm{~T} 12, \mathrm{R} 9$ & UTM 0492561, 5550239 & 1 & R.L/AXYS/EX \\
\hline Sept 8, 1996 & $\mathrm{~T} 13, \mathrm{R} 9$ & UTM 0498711, 5550249 & 1 & R.L/AXYS/Ex \\
\hline Sept 8, 1996 & $\mathrm{~T} 13, \mathrm{R} 9$ & UTM 0498711, 5550249 & 1 & R.L/AXYS/Ex \\
\hline Sept 8, 1996 & $\mathrm{~T} 13, \mathrm{R} 9$ & UTM 0490740,5550368 & 1 & R.L/AXYS/EX \\
\hline Sept 10,1996 & $\mathrm{~T} 13, \mathrm{R} 9$ & UTM 0489528,5550257 & 1 & R.L/AXYS/EX \\
\hline Sept 14,1996 & $\mathrm{~T} 13, \mathrm{R} 9$ & UTM 0491554,5550275 & 1 & R.L/AXYS/EX \\
\hline June 26,1995 & $\mathrm{~T} 12, \mathrm{R} 8$ & UTM 0498000,5543700 & 1 & R.L/AXYS/EX \\
\hline June 26,1995 & $\mathrm{~T} 12, \mathrm{R} 8$ & UTM 0498000,5543700 & 1 & R.L/AXYS/EX \\
\hline June 4, 1996 & $\mathrm{~T} 13, \mathrm{R} 8$ & UTM 0498018,5544546 & 9 & R.L/AXYS/EX \\
\hline Sept 7, 1996 & $\mathrm{~T} 13, \mathrm{R} 8$ & UTM 0499673, 5550274 & 1 & R.L/AXYS/EX \\
\hline Sept 7, 1996 & $\mathrm{~T} 13, \mathrm{R} 8$ & UTM 0496710,5550190 & 1 & R.L/AXYS/EX \\
\hline Sept 7, 1996 & $\mathrm{~T} 13, \mathrm{R} 8$ & UTM 0502140,5550230 & 1 & R.L/AXYS/EX \\
\hline Sept 9,1996 & $\mathrm{~T} 13, \mathrm{R} 8$ & UTM 0499919,5550328 & 1 & R.L/AXYS/Ex \\
\hline Sept 10, 1996 & $\mathrm{~T} 13, \mathrm{R} 8$ & UTM 0496443,5546470 & 1 & R.L/AXYS/EX \\
\hline Sept 10,1996 & $\mathrm{~T} 13, \mathrm{R} 8$ & UTM 0496411,5546409 & 1 & R.L/AXYS/Ex \\
\hline Sept 12, 1996 & $\mathrm{~T} 13, \mathrm{R} 8$ & UTM 0496659,5550239 & 1 & R.L/AXYS/EX \\
\hline
\end{tabular}




\begin{tabular}{|c|c|c|c|c|}
\hline $1979-83$ & $\mathrm{~T} 13, \mathrm{R} 8$ & Along Hwy 524, Tp.13-R.8-W4 & numerous & L. Powell \\
\hline Aug 21, 1996 & $\mathrm{~T} 13, \mathrm{R} 8$ & UTM 0495100,5550230 & 1 & R.L/AXYS/Ex \\
\hline Aug 23, 1996 & T13,R8 & UTM 0494100,5550250 & 1 & R.LAAXYS/EX \\
\hline Aug 23, 1996 & $\mathrm{~T} 13, \mathrm{R} 8$ & UTM 0493250,5550250 & 1 & R.L/AXYS/EX \\
\hline Sept 10, 1996 & $\mathrm{~T} 14, \mathrm{R} 9$ & UTM 0490885, 5550329 & 1 & R.L/AXYS/EX \\
\hline Sept 10, 1996 & T14,R9 & UTM 0488239,5550304 & 1 & R.L/AXYS/EX \\
\hline Sept 11, 1996 & $\mathrm{~T} 14, \mathrm{R} 9$ & UTM 0488289,5550217 & 1 & R.L/AXYS/EX \\
\hline $1979-83$ & $\mathrm{~T} 12, \mathrm{R} 7$ & W of Redcliffe, banks of South Saskatchewan R. & numerous & L. Powell \\
\hline 1987 & $\mathrm{~T} 12, \mathrm{R} 7$ & sensitive information(4) & Den? & Cottonwood (1987) \\
\hline Sept 2, 1996 & $\mathrm{~T} 12, \mathrm{R} 7$ & UTM 0507219,5537302 & 1 & R.L/AXYS/Ex \\
\hline Sept 3, 1996 & T12,R7 & UTM 0507834,5538301 & 1 & R.L/AXYS/EX \\
\hline Sept 7, 1996 & $\mathrm{~T} 12, \mathrm{R} 7$ & UTM 0507296,5537406 & 1 & RL/AXYS/Ex \\
\hline Sept 7, 1996 & $\mathrm{~T} 12, \mathrm{R} 8$ & UTM 0500300,5540600 & 1 & R.L/AXYS/Ex \\
\hline Sept 9,1996 & $\mathrm{~T} 12, \mathrm{R} 8$ & UTM 0499700, 5537600 & 1 & R.L/AXYS/EX \\
\hline Sept 9,1996 & $\mathrm{~T} 12, \mathrm{R} 7$ & UTM 0508064, 5540529 & 1 & R.L/AXYS/Ex \\
\hline Sept 9,1996 & $T 12, R 8$ & UTM 0500500,5540700 & 1 & R.L/AXYS/Ex \\
\hline Sept 9,1996 & $\mathrm{~T} 12, \mathrm{R} 8$ & UTM 0500500,5540700 & 1 & R.L/AXYS/EX \\
\hline Sept 9,1996 & $\mathrm{~T} 12, \mathrm{R} 8$ & UTM 0500500,5540700 & 1 & R.L/AXYS/Ex \\
\hline Sept 10, 1996 & $\mathrm{~T} 12, \mathrm{R} 8$ & UTM 0500400,5540600 & 1 & R.L/AXYS/Ex \\
\hline Sept 10, 1996 & T12,R8 & UTM 0499851,5538512 & 1 & R.L/AXYS/EX \\
\hline Sept 10, 1996 & T12,R8 & UTM 0500619,5538264 & 1 & R.L/AXYS/Ex \\
\hline Sept 13,1996 & T12,R.8 & UTM 0500400,5540600 & 1 & R.L/AXYS/EX \\
\hline Sept 13, 1996 & $\mathrm{~T} 12, \mathrm{R} 8$ & UTM 0499652,5537743 & 1 & R.L/AXYS/EX \\
\hline Sept 15,1996 & T12,R8 & UTM 0500300,5540550 & 1 & R.L/AXYS/EX \\
\hline Sept 19,1996 & $\mathrm{~T} 12, \mathrm{R} 8$ & UTM 0504000,5537300 & 1 & R.L/AXYS/EX \\
\hline Sept 24,1996 & $\mathrm{~T} 12, \mathrm{R} 8$ & UTM 0501500,5538350 & 1 & R.L/AXYS/EX \\
\hline Sept 25,1996 & $\mathrm{~T} 12, \mathrm{R} 8$ & UTM 0501300,5538250 & 1 & R.L/AXYS/EX \\
\hline Sept 25,1996 & $\mathrm{~T} 12, \mathrm{R} 8$ & UTM 0501500,5538350 & 1 & RL/AXYS/EX \\
\hline Sept 25,1996 & $\mathrm{~T} 12, \mathrm{R} 8$ & UTM 0500400,5540600 & 1 & R.L/AXYS/Ex \\
\hline Sept 27, 1996 & $T 12, R 8$ & UTM 0500500,5540500 & 1 & R.L/AXYS/EX \\
\hline Oct 3,1996 & $\mathrm{~T} 12, \mathrm{R} 8$ & UTM 0500400,5540600 & 1 & R.LAXYS/EX \\
\hline Oct 3, 1996 & $\mathrm{~T} 12, \mathrm{R} 8$ & UTM 0501600,5535550 & 1 & R.L/AXYS/EX \\
\hline Oct 4,1996 & $\mathrm{~T} 12, \mathrm{R} 7$ & UTM 0505683, 5537261 & 1 & R.L/AXYS/EX \\
\hline Oct 8,1996 & $\mathrm{~T} 12, \mathrm{R} 8$ & UTM 0500854,5540100 & 1 & R.L/AXYS/EX \\
\hline Sept 8, 1996 & $\mathrm{~T} 12, \mathrm{R} 8$ & UTM 0507834, 5538301 & 1 & R.L/AXYS/EX \\
\hline Sept 8,1996 & $\mathrm{~T} 12, \mathrm{R} 7$ & UTM 0507803,5538288 & 1 & R.L/AXYS/EX \\
\hline Sept 9,1996 & $\mathrm{~T} 12, \mathrm{R} 7$ & UTM 0506792, 5537345 & 1 & R.L/AXYS/EX \\
\hline Sept 12, 1996 & $\mathrm{~T} 12, \mathrm{R} 7$ & UTM 0507076, 5537265 & 1 & R.LAXXYS/EX \\
\hline Sept 13, 1996 & $\mathrm{~T} 12, \mathrm{R} 7$ & UTM 0506753, 5537228 & 1 & R.L/AXYS/Ex \\
\hline Sept 14, 1996 & $\mathrm{~T} 12, \mathrm{R} 7$ & UTM 0507051,5537274 & 1 & R.LAXYS/EX \\
\hline 1987 & $\mathrm{~T} 11, \mathrm{R} 6$ & sensitive information(4) & Den & Cottonwood (1987) \\
\hline June 5, 1995 & $\mathrm{~T} 11, \mathrm{R} 5$ & UTM 0524300,5527200 & 1 & R.L/AXYS/EX \\
\hline June14, 1996 & $\mathrm{~T} 10, \mathrm{R} 5$ & UTM 0524200,5524300 & 2 & R.L/AXYS/EX \\
\hline Sept 9,1996 & T11,R6 & UTM 0516427,5524436 & 1 & R.L/AXYS/Ex \\
\hline 1987 & $\mathrm{~T} 12, \mathrm{R} 6$ & sensitive information(4) & Den? & Cottonwood (1987) \\
\hline 1996 & $\mathrm{~T} 13, \mathrm{R} 7$ & sensitive information(4) & Den & D. Eslinger \\
\hline 1996 & $\mathrm{~T} 13, \mathrm{R} 6$ & sensitive information(4) & Den? & D. Eslinger \\
\hline Sept. 1996 & $\mathrm{~T} 12, \mathrm{R} 5$ & sensitive information(4) & Den & ASHI \\
\hline $1979-83$ & $\mathrm{~T} 12, \mathrm{R} 5$ & Medicine Hat & numerous & L. Powell \\
\hline 1987 & $\mathrm{~T} 13, \mathrm{R} 7$ & sensitive information(4) & Den & Cottonwood (1987) \\
\hline Sept 10, 1996 & $\mathrm{~T} 13, \mathrm{R} 7$ & UTM 0508717,5550214 & 1 & R.LAXYS/EX \\
\hline
\end{tabular}




\begin{tabular}{|c|c|c|c|c|}
\hline Sept 10, 1996 & $\mathrm{~T} 13, \mathrm{R} 7$ & UTM 0510504, 5550245 & 1 & R.L/AXYS/EX \\
\hline Sept 10, 1996 & $\mathrm{~T} 14, \mathrm{R} 8$ & UTM 0497264, 5550101 & 1 & R.L/AXYS/EX \\
\hline Sept 10, 1996 & $\mathrm{~T} 14, \mathrm{R} 8$ & UTM 0497772,5550242 & 1 & R.L/AXYS/Ex \\
\hline Sept 10, 1996 & $\mathrm{~T} 14, \mathrm{R} 8$ & UTM 0497394, 5550285 & 1 & R.L/AXYS/Ex \\
\hline Sept 13,1996 & $\mathrm{~T} 13, \mathrm{R} 8$ & UTM 0496410,5548867 & 1 & R.L/AXYS/Ex \\
\hline 1987 & $\mathrm{~T} 13, \mathrm{R} 6$ & sensitive information(4) & Den? & Cottonwood (1987) \\
\hline 1996 & $\mathrm{~T} 13, \mathrm{R} 6$ & sensitive information(4) & Den & D. Eslinger \\
\hline 1987 & $\mathrm{~T} 13, \mathrm{R} 5$ & sensitive information(4) & Den & Cottonwood (1987) \\
\hline 1996 & $\mathrm{~T} 13, \mathrm{R} 5$ & sensitive information(4) & Den & D. Eslinger \\
\hline 1996 & $\mathrm{~T} 13, \mathrm{R} 3$ & SW7-Tp.13-R.3-W4, Bull Springs Coulee & 2 & H. Troughton/ P P \\
\hline 1987 & $\mathrm{~T} 14, \mathrm{R} 5$ & sensitive information(4) & Den & Cottonwood (1987) \\
\hline 1987 & $\mathrm{~T} 14, \mathrm{R} 5$ & sensitive information(4) & Den? & Cottonwood (1987) \\
\hline 1996 & $\mathrm{~T} 14, \mathrm{R} 5$ & sensitive information(4) & Den & L. Powell \\
\hline 1996 & $\mathrm{~T} 14, \mathrm{R} 5$ & sensitive information(4) & Den & L. Powell \\
\hline 1996 & $\mathrm{~T} 14, \mathrm{R} 5$ & sensitive information(4) & Den & L. Powell \\
\hline 1996 & $\mathrm{~T} 14, \mathrm{R} 5$ & sensitive information(4) & Den & L. Powell \\
\hline 1996 & $\mathrm{~T} 15, \mathrm{R} 5$ & sensitive information(4) & Den & A. Didiuk/CWS* \\
\hline 1996 & $\mathrm{~T} 15, \mathrm{R} 5$ & sensitive information(4) & Den & A. Didiuk/CWS* \\
\hline 1996 & $\mathrm{~T} 15, \mathrm{R} 5$ & sensitive information(4) & Den & A. Didiuk/CWS* \\
\hline 1996 & $\mathrm{~T} 15, \mathrm{R} 5$ & sensitive information(4) & Den & A. Didiuk/CWS* \\
\hline 1996 & $\mathrm{~T} 15, \mathrm{R} 5$ & sensitive information(4) & Den & A. Didiuk/CWS* \\
\hline 1996 & $\mathrm{~T} 15, \mathrm{R} 5$ & sensitive information(4) & Den & A. Didiuk/CWS* \\
\hline July 14,1988 & $\mathrm{~T} 6, \mathrm{R} 2$ & $1.7 \mathrm{~km} \mathrm{~W}$ and $2.3 \mathrm{~km} \mathrm{~N}$ of junction of road to Schuler and Hwy 41 & 1 & Museum \# R1991.6 \\
\hline 1987 & $\mathrm{~T} 17, \mathrm{R} 3$ & sensitive information(4) & Den & Cottonwood (1987) \\
\hline 1996 & $\mathrm{~T} 17, \mathrm{R} 5$ & sensitive information(4) & Den & A. Didiuk/CWS* \\
\hline 1987 & $\mathrm{~T} 17, \mathrm{R} 3$ & sensitive information( 4 ) & Den & Cottonwood (1987) \\
\hline 1996 & $\mathrm{~T} 17, \mathrm{R} 4$ & sensitive information(4) & Den & A. Didiuk/CWS* \\
\hline 1987 & $\mathrm{~T} 17, \mathrm{R} 3$ & sensitive information( 4 ) & Den & Cottonwood (1987) \\
\hline 1996 & $\mathrm{~T} 19, \mathrm{R} 3$ & sensitive information(4) & Den & A. Didiuk/CWS* \\
\hline 1996 & $\mathrm{~T} 19, \mathrm{R} 3$ & sensitive information(4) & Den & A. Didiuk/CWS* \\
\hline 1987 & $\mathrm{~T} 17, \mathrm{R} 4$ & sensitive information(4) & Den & Cottonwood (1987) \\
\hline 1996 & $\mathrm{~T} 18, \mathrm{R} 4$ & Tp.18-R.4-W4, Suffield Base & numerous & L. Powell \\
\hline Oct, 1996 & $\mathrm{~T} 21, \mathrm{R} 11$ & sensitive information(4) & Den & ASHI \\
\hline 1987 & $\mathrm{~T} 21, \mathrm{R} 11$ & sensitive information(4) & Den? & Cottonwood (1987) \\
\hline 1987 & T21,R11 & sensitive information(4) & Den & Cottonwood (1987) \\
\hline Sept, 1996 & $\mathrm{~T} 21, \mathrm{R} 12$ & sensitive information(4) & Den & ASHI \\
\hline 1987 & $\mathrm{~T} 21, \mathrm{R} 12$ & sensitive information(4) & Den & Cottonwood (1987) \\
\hline July 25,1980 & $\mathrm{~T} 22, \mathrm{R} 9$ & $4 \mathrm{~km} \mathrm{~N}$ of Jenner Ferry & $\mathrm{n} / \mathrm{a}$ & Cottonwood (1986) \\
\hline May 16,1995 & $\mathrm{~T} 22, \mathrm{R} 9$ & UTM 0485300,5635300 & 8 & R.L./AXYS/Ex \\
\hline May 16,1995 & $\mathrm{~T} 22, \mathrm{R} 9$ & UTM 0485300,5635100 & 1 & R.L./AXYS/EX \\
\hline May 16,1995 & $\mathrm{~T} 22, \mathrm{R} 9$ & UTM 0485600,5634800 & 6 & R.L./AXYS/Ex \\
\hline May 17,1995 & $\mathrm{~T} 22, \mathrm{R} 9$ & UTM 0485600,5636000 & 1 & R.L./AXYS/Ex \\
\hline May 17,1995 & $\mathrm{~T} 22, \mathrm{R} 9$ & UTM 0485500,5635800 & 3 & R.L./AXYS/EX \\
\hline Aug 24, 1996 & $\mathrm{~T} 22, \mathrm{R} 9$ & UTM 0487600,5632350 & 1 & R.L./AXYS/EX \\
\hline Aug 24, 1996 & $\mathrm{~T} 22, \mathrm{R} 9$ & UTM 0487250,5634500 & 1 & R.L./AXYS/Ex \\
\hline Aug 24, 1996 & $\mathrm{~T} 22, \mathrm{R} 9$ & UTM 0487600,5632350 & 1 & R.L./AXYS/EX \\
\hline Aug 25,1996 & $\mathrm{~T} 22, \mathrm{R} 9$ & UTM 0487500,5632400 & 1 & R.L./AXYS/EX \\
\hline Aug 25, 1996 & $\mathrm{~T} 22, \mathrm{R} 9$ & UTM 0487300,5634400 & 1 & R.L./AXYS/EX \\
\hline Aug 25,1996 & $\mathrm{~T} 22, \mathrm{R} 9$ & UTM 0487500,5632400 & 1 & R.L./AXYS/Ex \\
\hline Aug 30,1996 & $\mathrm{~T} 22, \mathrm{R} 9$ & UTM 0484507,5636150 & 1 & R.L./AXYS/Ex \\
\hline Sept 2, 1996 & $\mathrm{~T} 22, \mathrm{R} 9$ & UTM 0484920,5637500 & 1 & R.L./AXYS/Ex \\
\hline
\end{tabular}




\begin{tabular}{|c|c|c|c|c|}
\hline Sept 2, 1996 & T22,R9 & UTM 0484900,5632600 & 1 & R.L./AXYS/EX \\
\hline Sept 2, 1996 & $\mathrm{~T} 22, \mathrm{R} 9$ & UTM 0484920, 5637500 & 1 & R.L./AXYS/EX \\
\hline Sept 3, 1996 & $\mathrm{~T} 22, \mathrm{R} 9$ & UTM 0486100,5632900 & 1 & R.L./AXYS/Ex \\
\hline Sept 8, 1996 & $\mathrm{~T} 22, \mathrm{R} 9$ & UTM 0487300,5634400 & 1 & R.L./AXYS/Ex \\
\hline Sept 11, 1996 & $\mathrm{~T} 22, \mathrm{R} 9$ & UTM 0484200,5636600 & 1 & R.L./AXYS/EX \\
\hline Sept 11, 1996 & $\mathrm{~T} 22, \mathrm{R} 9$ & UTM 0484200, 5636600 & 1 & R.L./AXYS/Ex \\
\hline Sept 14, 1996 & T22,R9 & UTM 0483800,5636800 & 1 & R.L./AXYS/Ex \\
\hline Sept 24,1996 & $\mathrm{~T} 22, \mathrm{R} 9$ & UTM 0484500,5637200 & 1 & R.L./AXYS/EX \\
\hline Sept 25,1996 & $\mathrm{~T} 22, \mathrm{R} 9$ & UTM 0484500,5636950 & 1 & R.L./AXYS/Ex \\
\hline Sept 25,1996 & T22,R9 & UTM 0484500,5636950 & 1 & R.L./AXYS/Ex \\
\hline Sept 28,1996 & $\mathrm{~T} 22, \mathrm{R} 9$ & UTM 0487000,5635400 & 1 & R.L./AXYS/EX \\
\hline Oct 27,1996 & $\mathrm{~T} 22, \mathrm{R} 9$ & UTM 0485400,5634400 & 1 & R.L./AXYS/EX \\
\hline May 17, 1995 & $\mathrm{~T} 22, \mathrm{R} 9$ & UTM 0485400,5636200 & 1 & R.L./AXYS/Ex \\
\hline May 17,1995 & $\mathrm{~T} 22, \mathrm{R} 9$ & UTM 0482900,5635000 & 7 & R.L./AXYS/Ex \\
\hline Sept 20, 1996 & $\mathrm{~T} 22, \mathrm{R} 9$ & UTM 0483300,5636900 & 1 & R.L./AXYS/EX \\
\hline Sept 20, 1996 & $\mathrm{~T} 22, \mathrm{R} 9$ & UTM 0483800,5636800 & 1 & R.L./AXYS/EX \\
\hline Aug 22, 1996 & $\mathrm{~T} 22, \mathrm{R} 9$ & UTM 0482400,5627800 & 1 & R.L./AXYS/EX \\
\hline Sept 14,1996 & $\mathrm{~T} 22, \mathrm{R} 9$ & UTM 0487300,5628500 & 1 & R.L./AXYS/Ex \\
\hline June 29,1995 & $\mathrm{~T} 22, \mathrm{R} 9$ & UTM 0483700,5624200 & 1 & R.L./AXYS/Ex \\
\hline June 26,1996 & $\mathrm{~T} 22, \mathrm{R} 9$ & UTM 0483814, 5621190 & 1 & R.L./AXYS/EX \\
\hline Sept 14, 1996 & $\mathrm{~T} 22, \mathrm{R} 9$ & UTM 0487600,5632400 & 1 & R.L./AXYS/EX \\
\hline June 27,1996 & T19,R11 & Hwy $544,19 \mathrm{~km}$ W. of Hwy 884 & 1 & R.L./AXYS/Ex \\
\hline June 27, 1996 & T19,R11 & Hwy $544,20 \mathrm{~km}$ W of Hwy 884 & 1 & R.L./AXYS/Ex \\
\hline June 27, 1996 & $\mathrm{~T} 19, \mathrm{R} 11$ & Hwy $544,21 \mathrm{~km} \mathrm{~W}$ of Hwy 884 & 1 & R.L./AXYS/Ex \\
\hline June 26, 1996 & $\mathrm{~T} 21, \mathrm{R} 9$ & Hwy $889200 \mathrm{~m}$ N of Jenner & 1 & R.L./AXYS/EX \\
\hline 1987 & $\mathrm{~T} 22, \mathrm{R} 6$ & sensitive information(4) & Den & Cottonwood (1987) \\
\hline 1991 & $\mathrm{~T} 22, \mathrm{R} 6$ & sensitive information(4) & 2 Dens & Hofman (1991) \\
\hline 1991 & $\mathrm{~T} 22, \mathrm{R} 6$ & sensitive information(4) & Den & Hofman (1991) \\
\hline 1987 & T22,R6 & sensitive information(4) & Den & Cottonwood (1987) \\
\hline 1991 & T22,R5 & sensitive information(4) & Den & Hofman (1991) \\
\hline 1987 & T22,R5 & sensitive information(4) & Den & Cottonwood (1987) \\
\hline 1987 & T22,R5 & sensitive information(4) & Den & Cottonwood (1987) \\
\hline 1991 & $\mathrm{~T} 21, \mathrm{R} 4$ & sensitive information(4) & Den & Hofman (1991) \\
\hline 1991 & $\mathrm{~T} 22, \mathrm{R} 4$ & sensitive information(4) & Den & Hofman (1991) \\
\hline 1987 & $\mathrm{~T} 22, \mathrm{R} 4$ & sensitive information(4) & Den & Cottonwood (1987) \\
\hline 1991 & $\mathrm{~T} 22, \mathrm{R} 4$ & sensitive information(4) & Den & Hofman (1991) \\
\hline 1987 & $\mathrm{~T} 22, \mathrm{R} 4$ & sensitive information(4) & Den & Cottonwood (1987) \\
\hline 1987 & $\mathrm{~T} 22, \mathrm{R} 4$ & sensitive information(4) & Den & Cottonwood (1987) \\
\hline 1991 & $\mathrm{~T} 22, \mathrm{R} 3$ & sensitive information(4) & Den & Hofman (1991) \\
\hline 1987 & $\mathrm{~T} 20, \mathrm{R} 1$ & sensitive information(4) & Den & Cottonwood (1987) \\
\hline 1996 & $\mathrm{~T} 20, \mathrm{R} 1$ & sensitive information(4) & Den & D. Eslinger \\
\hline 1987 & $\mathrm{~T} 20, \mathrm{R} 1$ & sensitive information(4) & Den & Cottonwood (1987) \\
\hline June, 1995 & $\mathrm{~T} 20, \mathrm{R} 1$ & sensitive information(4) & Den & ASHI \\
\hline 1987 & $\mathrm{~T} 21, \mathrm{R} 1$ & sensitive information(4) & Den & Cottonwood (1987) \\
\hline 1987 & $\mathrm{~T} 21, \mathrm{R} 1$ & sensitive information(4) & \#of Sm. Dens & Cottonwood (1987) \\
\hline Sept 3-4, 1991 & $\mathrm{~T} 23, \mathrm{R} 2$ & $2 \mathrm{~km} \mathrm{~S}$ of Empress turnoff on Hwy 41 & 1 & Hofman (1991) \\
\hline May 19, 1988 & $\mathrm{~T} 23, \mathrm{R} 1$ & Near overpass of Red Deer R., $1.7 \mathrm{~km} \mathrm{~N}$ of turnoff to Empress & 1 & Museum \# R-1991.3 \\
\hline 1991 & $\mathrm{~T} 23, \mathrm{R} 2$ & sensitive information(4) & Den & Hofman (1991) \\
\hline 1987 & $\mathrm{~T} 23, \mathrm{R} 2$ & sensitive information(4) & Den & Cottonwood (1987) \\
\hline Apr., 1987 & $\mathrm{~T} 23, \mathrm{R} 2$ & sensitive information( 4 ) & Den?? & ASHI \\
\hline Sept 8, 1996 & T24,R9 & UTM 0486700,5653800 & 1 & R.L./AXYS/Ex \\
\hline
\end{tabular}




\begin{tabular}{|c|c|l|c|c|}
\hline Sept 8, 1996 & T24,R9 & UTM 0486700, 5653800 & 1 & R.L./AXYS/Ex \\
\hline Sept 8, 1996 & T24,R9 & UTM 0486700, 5653800 & 1 & R.L./AXYS/Ex \\
\hline July, 1996 & T5,R22 & sensitive information(4) & Den? & K. Sabey \\
\hline
\end{tabular}

(1) Georeferences given as township (T), range (R) west of the 4th meridian

(2) Den?=Suspected den but unconfirmed; Den??=Known den but unsure if inhabited by Prairie Rattlesnakes

(3) Sources: UAMR=University of Alberta Museum records; Leth. F\&W=Lethbridge Fish and Wildlife office; ROM=Royal Ontario Museum; NMC=National Museum of Canada; ASHI=Alberta Snake Hibernaculum Inventory; PP=Palliser Pipeline Project; CWS=Canadian Wildlife Service; *=Unpublished data; R.L./AXYS/Ex=Rick Lauzon/AXYS Environmental Consultants/Express Pipeline Ltd.

(4) Precise den locations are not provided. Detailed information will be provided as necessary to agencies/individuals with a demonstrated need to know 
APPENDIX 3. Historic (pre-1978) site records for Prairie Rattlesnakes in Alberta. Numbered sites are mapped on Figure 1.

\begin{tabular}{|c|c|c|c|c|}
\hline Site \# & Date & Georeference(a) & Site Description & Source(b) \\
\hline 1 & May 26, 1966 & T8, R22 & Near Lethbridge & UAM \\
\hline 1 & before 1961 & $\mathrm{~T} 8, \mathrm{R} 22$ & Lethbridge & ROM (see Logier \& Toner 1961) \\
\hline 2 & before 1961 & $\mathrm{~T} 9, \mathrm{R} 22$ & Diamond City & Logier \&Toner (1961) \\
\hline 3 & July 20,1970 & $\mathrm{~T} 1, \mathrm{R} 13$ & $20 \mathrm{mi} \mathrm{E}, 4.5 \mathrm{mi}$. S of Milk River & NMC (No. 14275) \\
\hline 4 & Jun.1951; Aug. 7,1957 & $\mathrm{T} 2, \mathrm{R} 4$ & $4 \mathrm{mi} \mathrm{N}$ Onefour & Lewin (1963) \\
\hline 4 & Aug. 7,$1951 ;$ no date 1951 & $\mathrm{~T} 2, \mathrm{R} 4$ & Onefour & UAM \\
\hline 4 & June 1957 & $\mathrm{~T} 2, \mathrm{R} 4$ & 4.5mi. N Onefour & UAM \\
\hline 5 & before 1961 & $\mathrm{~T} 12, \mathrm{R} 12$ & 40mi. W Medicine Hat & Logier \&Toner (1961) \\
\hline 6 & Aug. 24, 1975 & $\mathrm{~T} 13, \mathrm{R} 13$ & Bow R., $1 \mathrm{mi}$. E of Hayes & UAM \\
\hline 7 & Undated; August 1951 & $\mathrm{~T} 12, \mathrm{R} 5$ & Medicine Hat & UAM \\
\hline 7 & May, 1973 & $\mathrm{~T} 12, \mathrm{R} 5$ & Medicine Hat & ROM \\
\hline 7 & June 8,1894 & $\mathrm{~T} 12, \mathrm{R} 5$ & Medicine Hat & NMC (No. 39) \\
\hline 7 & before 1961 & T12, R5 & Medicine Hat & ROM (see Logier \& Toner 1961) \\
\hline 8 & June 2, 1951 & $\mathrm{~T} 13, \mathrm{R} 7$ & Redcliff & UAM \\
\hline 8 & before 1961 & $\mathrm{~T} 13, \mathrm{R} 7$ & Redcliff & Logier \& Toner (1961) \\
\hline 9 & June 30,1957 & $\mathrm{~T} 13, \mathrm{R} 5$ & $\mathrm{~N}$ of Medicine Hat & NMC (No. 3428) \\
\hline 10 & June 25,1971 & $\mathrm{~T} 14, \mathrm{R} 5$ & 12mi. NE of Medicine Hat & UAM \\
\hline 11 & May 8, 1971 & T20, R1 & $14 \mathrm{mi} . \mathrm{S}, 3 \mathrm{mi} . \mathrm{W}$ of Empress & UAM \\
\hline 12 & July 17,1950 & $\mathrm{~T} 23, \mathrm{R} 1$ & Empress & UAM \\
\hline 13 & June 24, 1976 & $\mathrm{~T} 23, \mathrm{R} 2$ & N of Red Deer R., $10 \mathrm{mi}$. N of Bindloss & Cottonwood Consultants (1986) \\
\hline 14 & Aug. 19, 1951 & $\mathrm{~T} 11, \mathrm{R} 20$ & Iron Springs & UAM \\
\hline 14 & before 1961 & $\mathrm{~T} 11, \mathrm{R} 20$ & Iron Springs & MCZ (see Logier \&Toner 1961) \\
\hline 15 & 1934 & $\mathrm{~T} 18, \mathrm{R} 22$ & 50mi. E High River & Fowler (1934, see Logier \&Toner 1961) \\
\hline 16 & July 7,1960 & T1, R5 & $16 \mathrm{mi} \mathrm{W}$ of Wildhorse & NMC (No. 9598) \\
\hline 16 & June 2,1962 & $\mathrm{~T} 1, \mathrm{R} 5$ & Milk R., $17 \mathrm{mi} \mathrm{W}$ of Wildhorse & UAM; Lewin (1963) \\
\hline 16 & June $4 \& 16,1962$ & $\mathrm{~T} 1, \mathrm{R} 5$ & Milk R., $17 \mathrm{mi} . \mathrm{W}, 1 \mathrm{mi}$. N of Wildhorse & UAM \\
\hline 16 & July 18,1975 & $\mathrm{~T} 1, \mathrm{R} 5$ & $20 \mathrm{mi}$. W of Wildhorse & UAM \\
\hline 16 & July 18,1975 & $\mathrm{~T} 1, \mathrm{R} 5$ & $15 \mathrm{mi}$. W of Wildhorse & UAM \\
\hline 16 & June 2-6, 1962 & $\mathrm{~T} 1, \mathrm{R} 5$ & $17 \mathrm{mi} \mathrm{W}, 1 \mathrm{mi} . \mathrm{N}$ of Wildhorse (Milk R.) & Lewin (1963) \\
\hline 17 & Sept, 4, 1975 & $\mathrm{~T} 2, \mathrm{R} 6$ & Pinhom Grazing Lease, Milk R. & NMC (No. 17425) \\
\hline 18 & Oct. 15,1932 & T5, R6 & S of Manyberries & NMC (No. 1747) \\
\hline 18 & 1935 & T5, R6 & W of Manyberries & NMC (No. 2046) \\
\hline 18 & before 1961 & T5, R6 & Manyberries & ROM (see Logier \& Toner 1961) \\
\hline 19 & Sept. 1, 1935 & T6, R9 & Etzikom & NMC (No. 1975) \\
\hline 20 & Summer, 1923 & $\mathrm{~T} 10, \mathrm{R} 13$ & Grassy Lake & NMC (No. 1019) \\
\hline 21 & Aug 17,1950 & T11, R8 & N of Whitla & UAM \\
\hline 22 & July 4, 1957 & T13, R1 & $22.1 \mathrm{mi} \mathrm{S}$ of Schuler & NMC (No. 3436) \\
\hline 23 & July 6,1957 & $\mathrm{~T} 15, \mathrm{R} 4$ & $0.7 \mathrm{mi} \mathrm{N}$ of Bowmanton P.O. & NMC (No. 3439) \\
\hline 24 & before 1961 & $\mathrm{~T} 15, \mathrm{R9}$ & Suffield & Logier \& Toner (1961) \\
\hline 25 & before 1961 & $\mathrm{~T} 15, \mathrm{R} 10$ & Alderson & Logier \& Toner (1961) \\
\hline 26 & June 21,1970 & T19, R1 & 20mi. S of Empress & UAM \\
\hline 27 & 1957 & T29, R19 & $0.8 \mathrm{~km}$ upstream of bridge, Drumheller & Pendlebury (1977) \\
\hline 28 & 1943 & $\mathrm{~T} 33, \mathrm{R} 23$ & Trochu & Pendlebury (1977) \\
\hline 29 & 1934 & $\mathrm{~T} 21, \mathrm{R} 27$ & $21.6 \mathrm{~km} \mathrm{SE}$ of Calgary & Pendlebury (1977) \\
\hline$-(c)$ & 1934 & - & $100 \mathrm{~km} \mathrm{SE}$ of Calgary & Fowler 1934 (see Pendlebury 1977) \\
\hline
\end{tabular}

(a) Georeferences are given as township (T), range (R) west of the 4th meridian

(b) UAM=University of Alberta Museum; ROM=Royal Ontario Museum; NMC=National Museum of Canada

(c) not mapped 


\section{List of Titles In This Series}

(as of September 1997)

No. 1 Status of the Piping Plover (Charadrius melodus) in Alberta, by David R. C. Prescott. 19 pp.

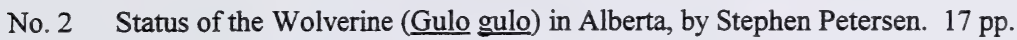

No. 3 Status of the Northern Long-eared Bat (Myotis septentrionalis) in Alberta, by M. Carolina Caceres and M. J. Pybus. 19 pp.

No. 4 Status of the Ord's Kangaroo Rat (Dipodomys ordii) in Alberta, by David L. Gummer. 16 pp.

No. 5 Status of the Eastern Short-horned Lizard (Phrynosoma douglassii brevirostre) in Alberta, by Janice D. James, Anthony P. Russell and G. Lawrence Powell. 20 pp.

No. 6 Status of the Prairie Rattlesnake (Crotalus viridis viridis) in Alberta, by Sheri M. Watson and Anthony P. Russell. 26 pp.

No. 7 Status of the Swift Fox (Vulpes velox) in Alberta, by Susan E. Cotterill. 17pp.

No. 8 Status of the Peregrine Falcon (Falco peregrinus anatum) in Alberta, by Petra Rowell and David P. Stepnisky. In Preparation.

No. 9 Status of the Northern Leopard Frog (ana pipiens) in Alberta, by Greg Wagner. In Preparation.

No. 10 Status of the Sprague's Pipit (Anthus spragueii) in Alberta, by David R. C. Prescott. 14 pp.

No. 11 Status of the Burrowing Owl (Speotyto cunicularia hypugaea) in Alberta, by Troy I. Wellicome. $21 \mathrm{pp}$. 
NOTES 
NOTES 
NOTES 

National Library of Canada

Bibliothèque nationale du Canada

33286513566964 